\title{
Research Paper \\ The Effect of Teaching with a Myth Buster Scientific Method on the Critical and Analytical Thinking of Students: The Moderating Role of Social Achievement Goals
}

Etrat Alzahra Ghanaat Pisheh ${ }^{* 1}$, Yaser NejatyJahromy ${ }^{2}$, Rahim Badri Gargari ${ }^{3}$, Touraj Hashemi ${ }^{4}$, Eskandar Fathi-Azar ${ }^{4}$

1. Ph.D. of Educational Psychology, Faculty of Education and Psychology Sciences, University of Tabriz, Iran

2. Research Fellow, Institute of Theoretical and Physical Chemistry, University of Bonn, Germany

3. Associate Professor, Department of Educational Psychology, Faculty of Education and Psychology Sciences, University of Tabriz, Iran

4. Professor, Department of Educational Psychology, Faculty of Education and Psychology Sciences, University of Tabriz, Iran

Citation: Ghanaat Pisheh EZ, NejatyJahromy Y, Badri Gargari R, Hashemi T, Fathi-Azar E. The effect of teaching with a myth buster scientific method on the critical and analytical thinking of students: the moderating role of social achievement goals. Quarterly Journal of Child Mental Health. 2020; 7(1): 220-232.

http://dx.doi.org/10.29252/jcmh.7.1.19

\section{A R T I C L E I N F O}

\section{Keywords:}

Myth buster, critical and analytical thinking, social achievement goals

Received: 29 May 2018

Accepted: 7 Apr 2019

Available: 20 Jun 2020

\section{A B S T R A C T}

Background and Purpose: Development of critical and analytical thinking is an important research goal and researches have been always concerned with searching for new methods of critical and analytical thinking and testing them for finding the most efficient methods. Therefore, present research aimed to investigate the effect of teaching with a myth busting method on the critical and analytical thinking of students with the moderating role of social achievement goals.

Method: This study was a quasi-experimental research with pretest-posttest control group design. The study sample included 65 female students studying at the $8^{\text {th }}$ grade of middle school in Tehran in the academic year 2016-2017, who were selected by multi-stage cluster sampling method and then randomly assigned to either the experimental or the control group. Social Motivational Orientations Scale (Allen, 2003) and Critical Thinking Test (Cornell, 1985) were used for pretest. The experimental group received 10 sessions of thinking and life style with scientific myth buster method. Also, students with higher and lower social achievement goal orientation were separated from each other by using Social Goal Questionnaire. Finally, the groups underwent the posttest. Data were analyzed by factorial analysis of covariance.

Results: Data analysis (by using social goals as the moderator) showed that teaching with myth buster scientific method was significantly effective in improving the critical thinking of students $(\mathrm{F}=36.01, \mathrm{P}<0.001)$.

Conclusion: The benefits of the myth buster scientific method combined with the identification of social achievement goals can approve its use as an appropriate educational method to improve critical thinking skills. Students with higher social goals have higher participation in class activities, which in turn leads to their higher critical thinking. This myth buster scientific method can improve critical thinking skills.

\footnotetext{
* Corresponding author: Etrat Alzahra Ghanaat Pisheh, Ph.D. of Educational Psychology, Faculty of Education and Psychology Sciences, University of Tabriz, Iran.

E-mail addresses: Psychoanalyses@outlook.com
}

2476-5740/ (C) 2019 The Authors. This is an open access article under the CC BY-NC-ND license (https://creativecommons.org/licenses/by-nc-nd/3.0/). 


\section{تأثير آموزش به شيوهُ افسانهزدائى علمى بر تفكر تحليلى انتقادى دانش آموزان با توجه به اهداف ييشرفت اجتماعى}

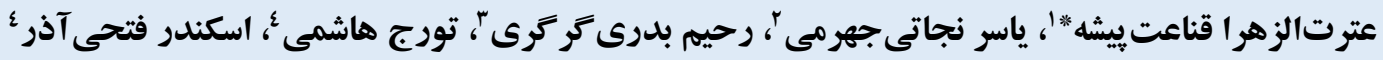

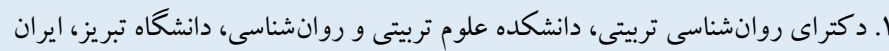

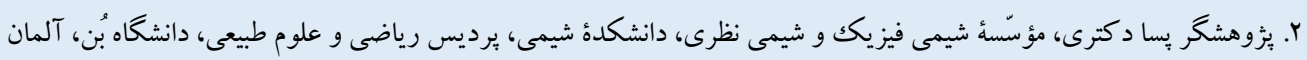

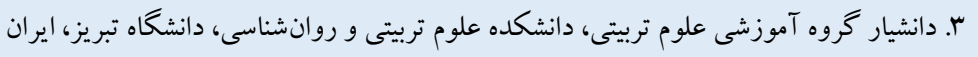

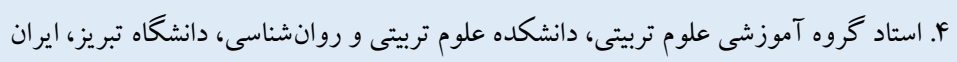

\section{جكيده}

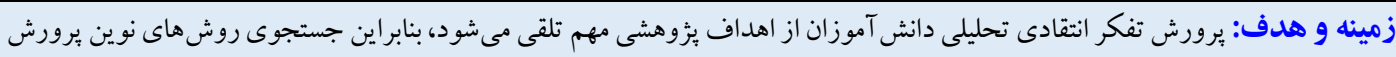

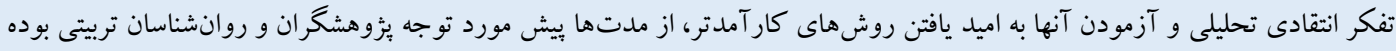

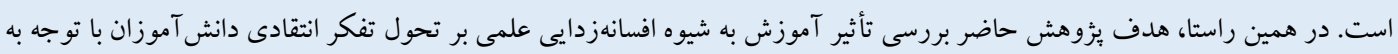
نقش اهداف بيشرفت اجتماعى بود.

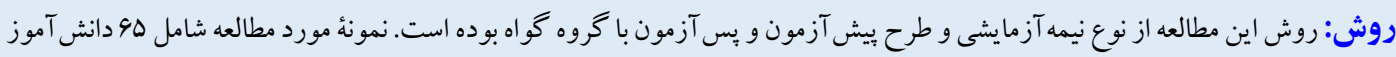

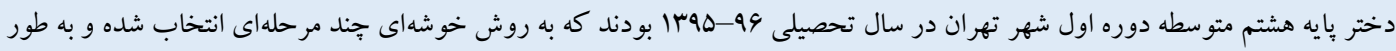

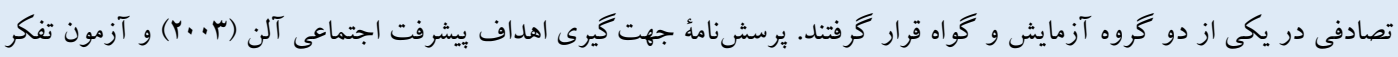

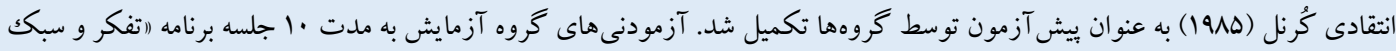

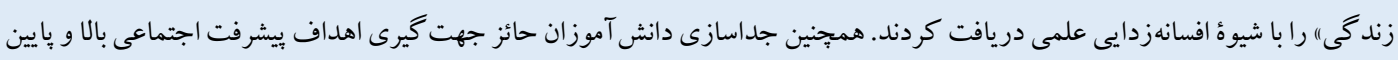

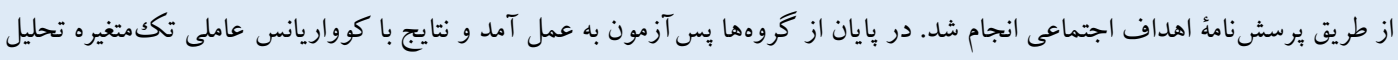
يافتهها: يافتههاى حاصل از تحليل كوواريانس عاملى تككمتغيره (با تعديل گرى اهداف اجتماعى) نشان داد آموزش مبتى بر افسانهز دايى

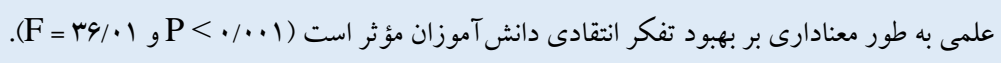

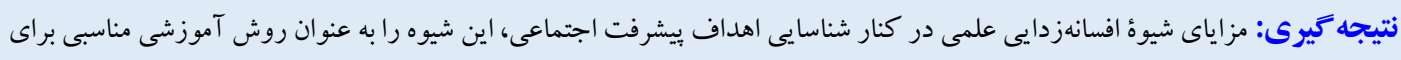

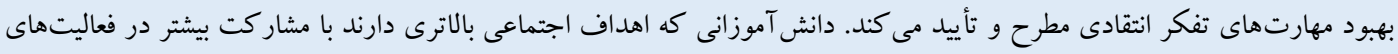

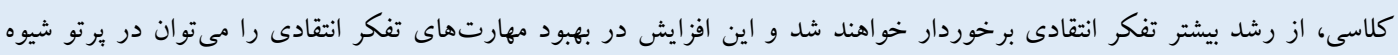

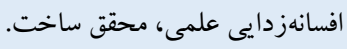

مشخصات مقاله

كليدوازهها: افسانهزدايى علمى، تيدازهان

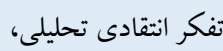
اهداف بيشرفت اجتماعى تئى 
نقد كنند و به يروردن فضاى برسشخرى و شكّاكيت در ميان شاكر دانشان مشتاق باشند (r و 9).

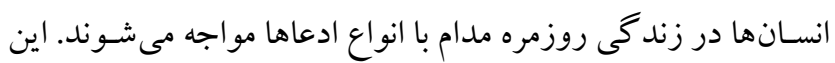

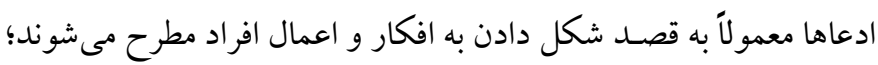

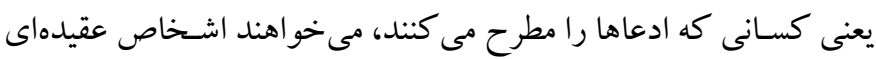

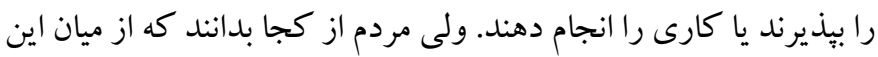

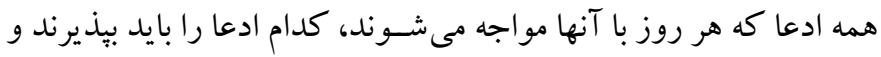

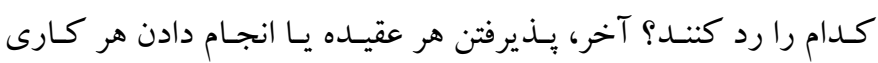

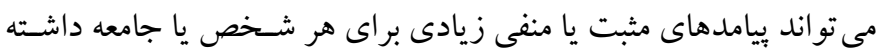

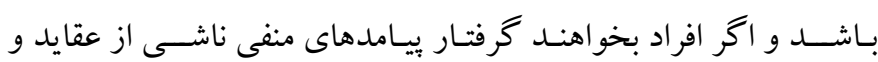

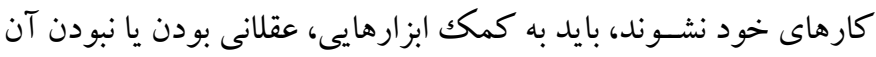

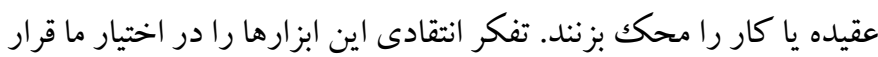

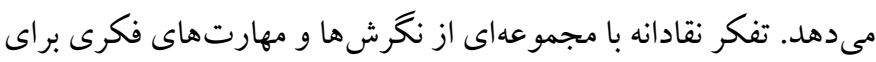
ارزيابى و محكك زدن ادعاها و استدلالها به كار مى آيند (V).

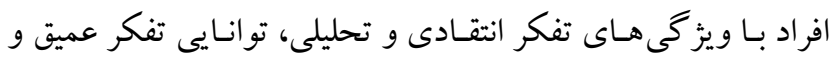

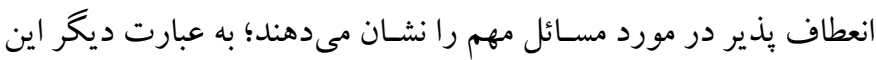

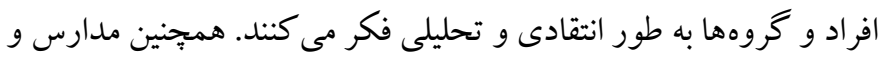

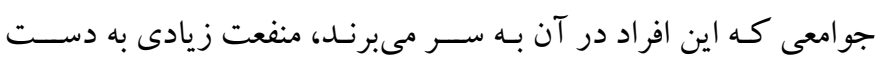

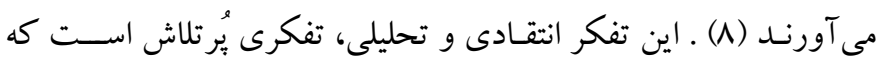

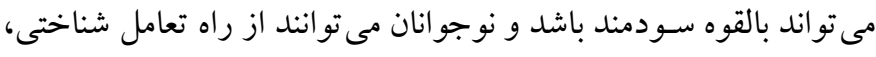

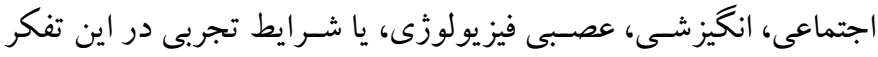

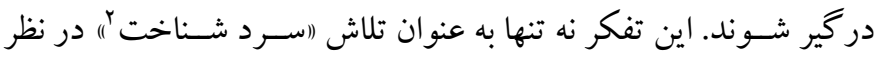

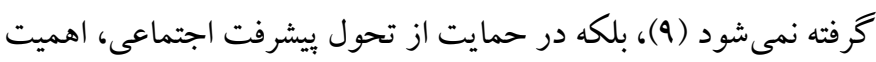

اهميـت تفكر انتــادى دانش آموزان، امكـان يرورش آن، راههـاى

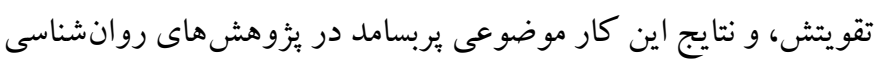

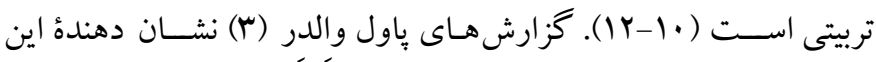

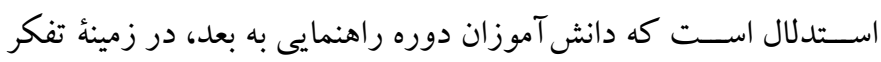

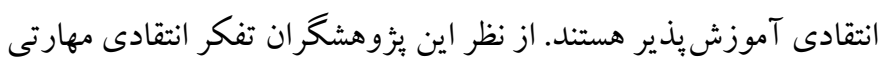

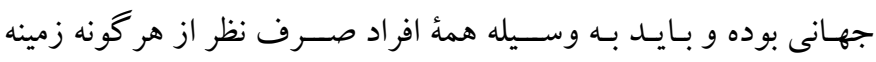

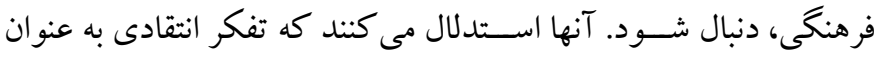

2. Coldly cognitive
مقلهم

در نظام آموزش و يرورش ما، شيوهاى از آموزش مورد قبول است كه در

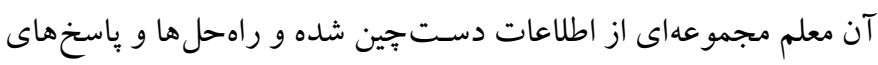

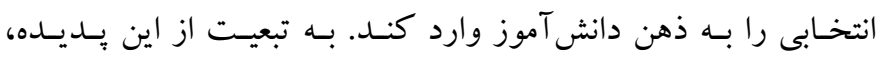

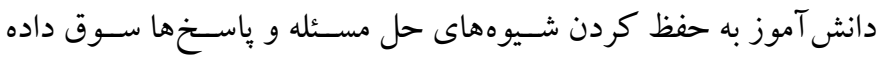
مىشـود و در جهت به يادسـيارى اين مطالب تلاش مى كند؛ بنابراين در

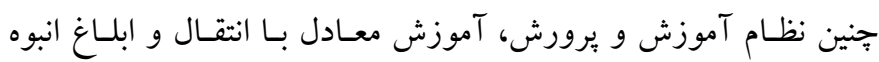

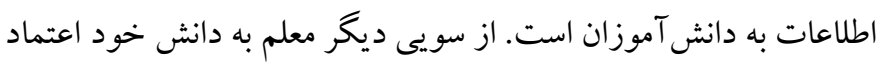

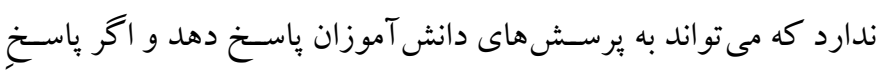

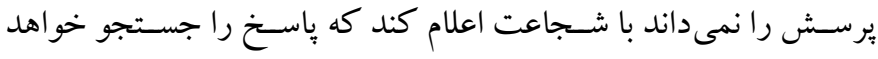

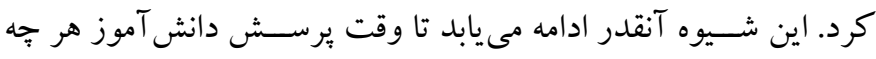

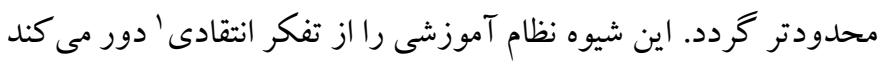

از نظر هـالبرن (Y) تفكر انتقـادى مهارتها و راهكارهاى شــناختى

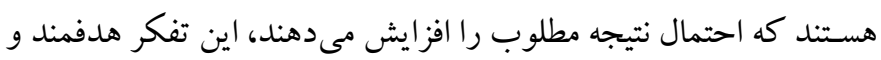

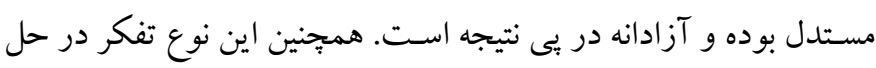

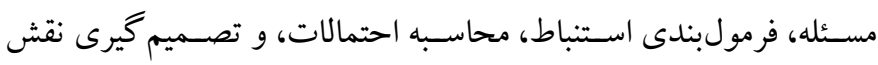

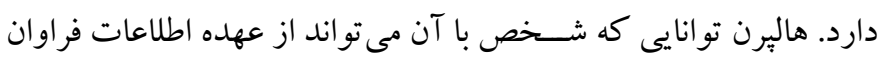

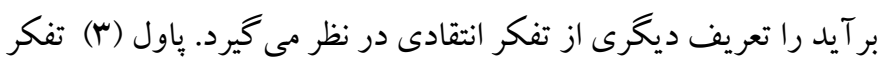

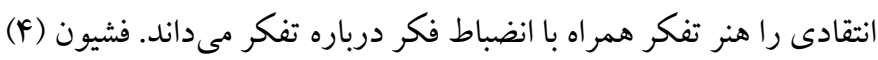

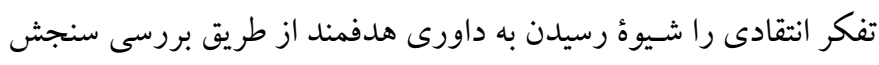

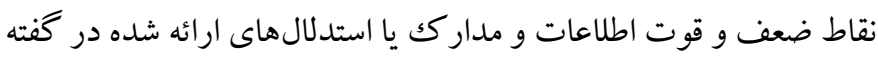
يا متن مى مداند. نظريه هاى تفكر انتقادى بيشتر در نيمهُ دوم سدهُ بيستم در غرب تدوين

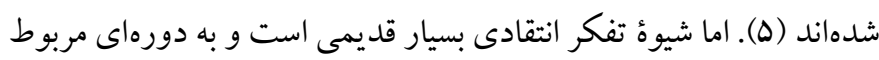

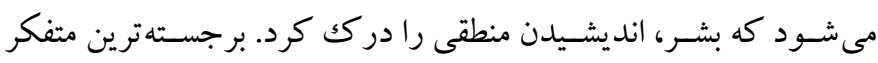

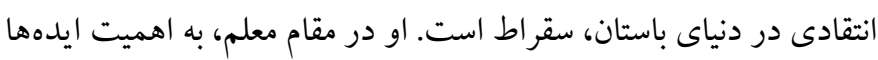

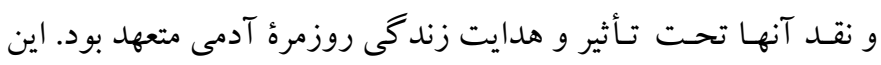

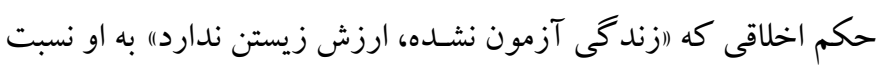

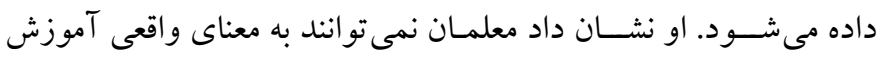

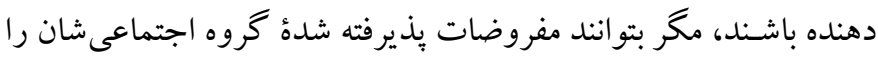

1. Critical thinking 
بحثها است؛ به طورى كه نتايج منطقى درباره اين ادعاها ترسيم مىشود.

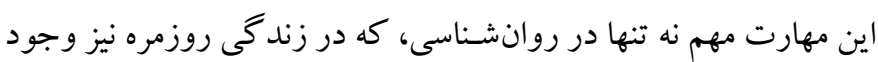

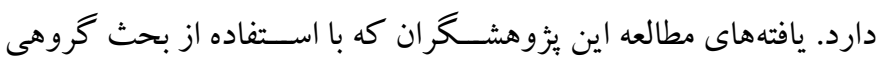

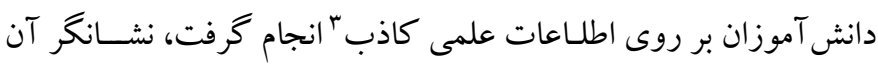

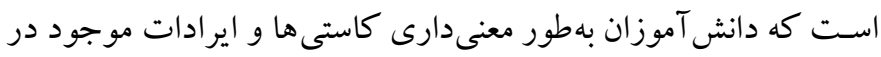
مجموعه ادعاها را به طور صحيح تشخيص دادند.

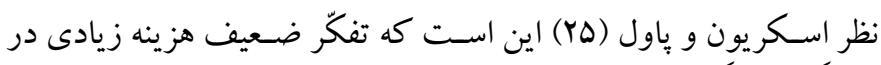

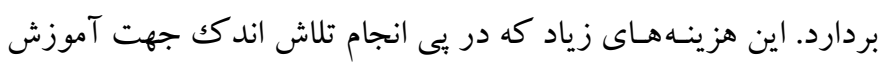

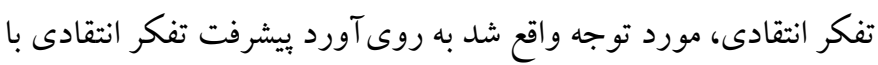

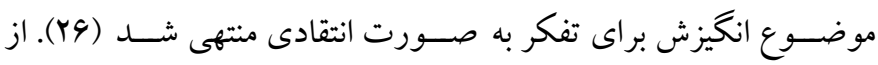

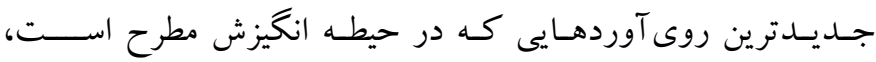
جهت گيرى اهداف بيشرفت اجتماعى است. اهداف ييشرفت اجتماعى به روديه

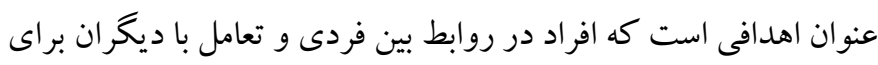

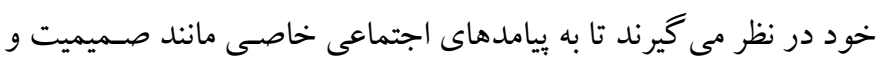

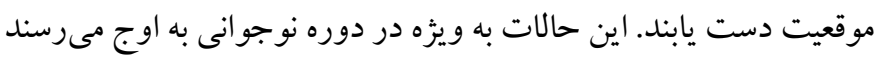

(YV)

اهــاف اجتمـاعى و رابطة آن با زندگى اجتماعى هم در نوجوانان و

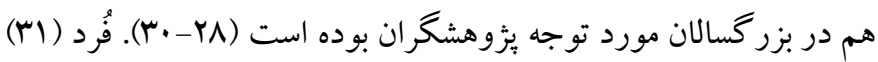

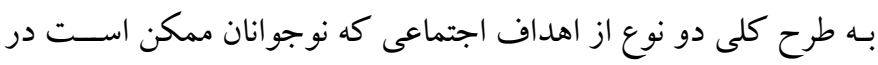

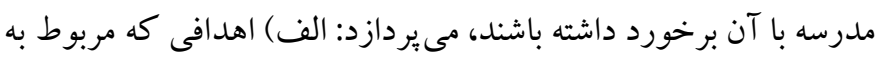
خود ادعايى و نشــان دادن خود در موقعيت ها (اهداف اجتماعى ســطح يايين) هســتند، و ب) اهدافى كه به صــميميت و حفظ رفاقتها ارتباط

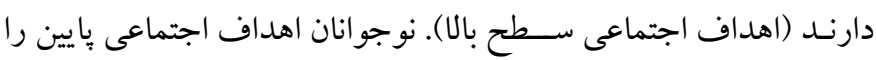
براى حفظ يا ارتقا خود به كار مىبرند؛ اين اهداف شامل تمايل نوجوانان

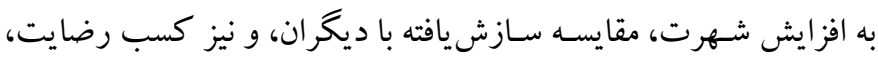

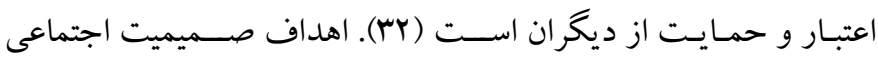
نوجوانان كه گاهى اهداف دوست كُ ايى ناميده شده، به حفظ دوستى با

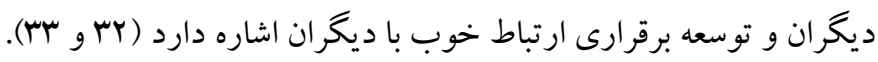

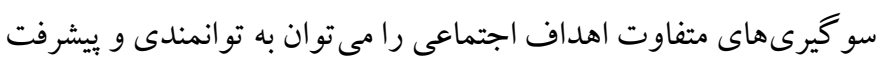

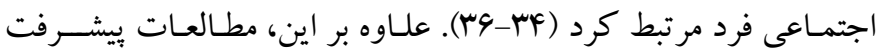

3. Pseudoscience activity
تفكر سـطح بالا، بايد محور برنامه آموزشسى درسـى بوده و يايهاى براى

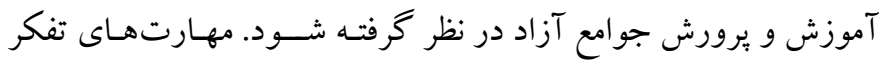

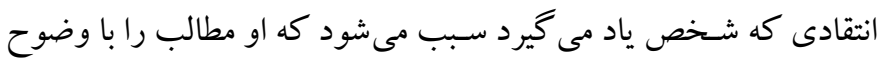

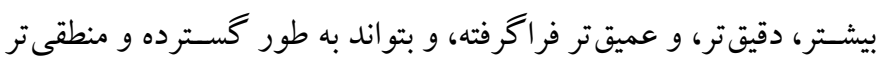

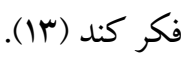
در سـالهاى اخير تلاشهاى مســمر و دامنهدارى جهت شـكل دهى مــلهــاى نظـرى جهـت عمليـاتى كردن آموزش تفكر انتقـادى در

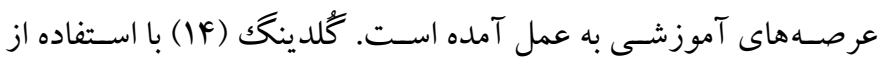

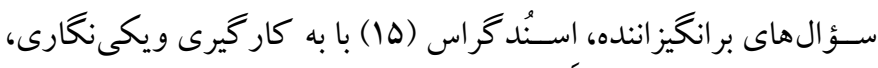

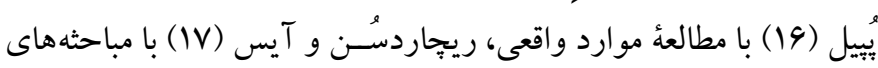

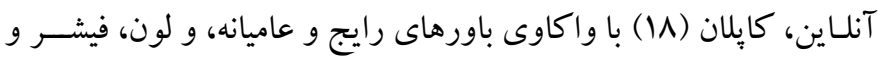

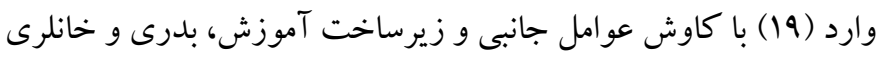

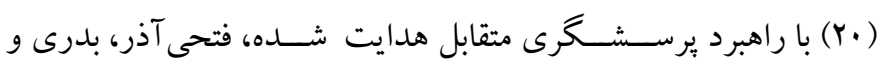
احرارى (YI) آموزش فن شش كلاه دوبونو ' و بدرى و قناعتيشيشه (YY)

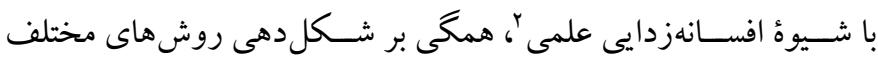

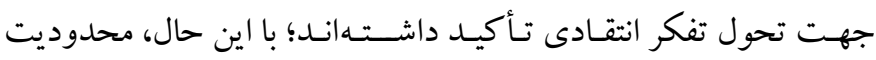
اجرايى كردن آنها در كلاس درس، نياز به تلاشهاى جديد در اين عرصه

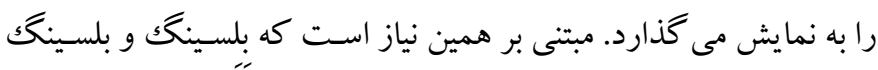

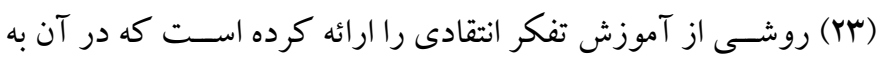

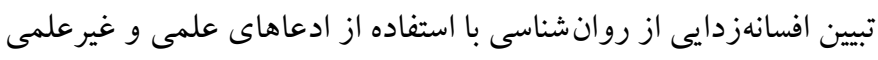

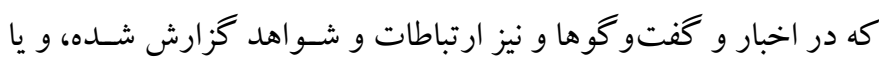

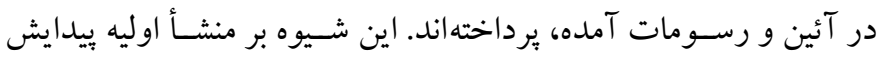

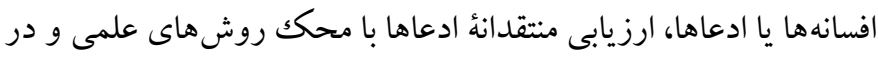

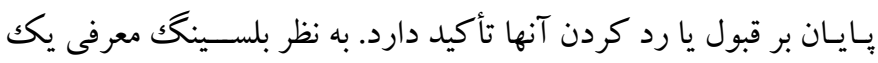

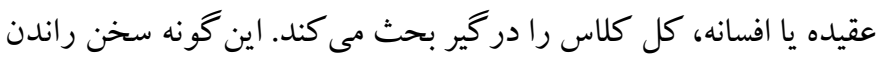

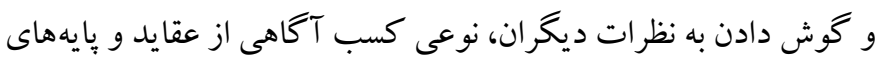

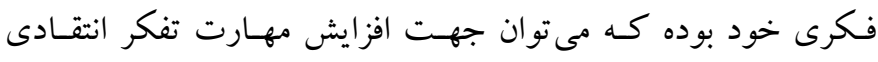
فراگير ان بهره خرفت. بر اسـاس نظر آدام و مانسُن (YY) افسانهزدايى علمى يكى يكى از راههاى

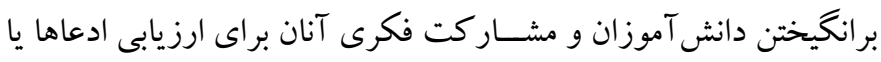


در مطالعات اخيرتأثير مثبت استفاده از ابزار نوين سـامانهُ جمع آورى

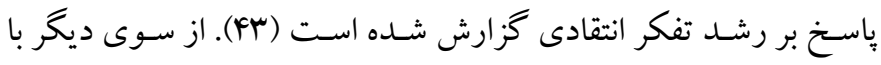

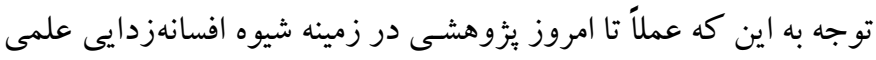
و اهـداف ويشـــرفت اجتماعى نشــده اســت و همجنين با توجه به نتايج

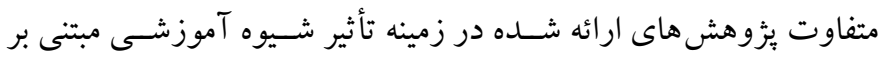

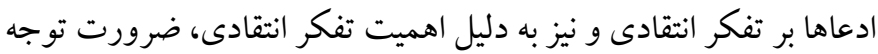

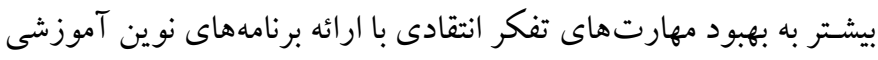

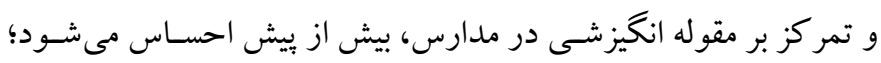

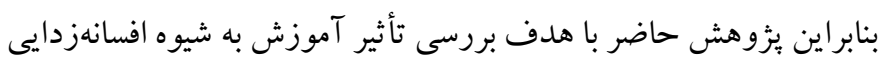

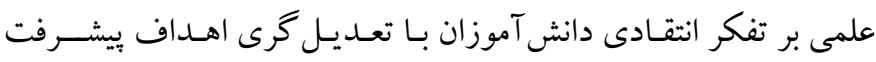

$$
\text { اجتماعى (سطوح بالا - يايين) اجرا شد. }
$$

روش

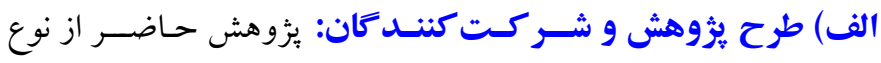

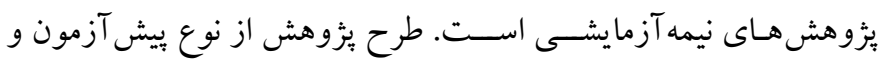

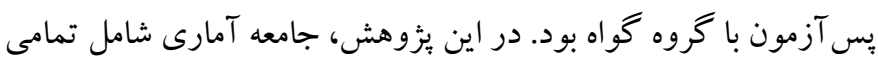

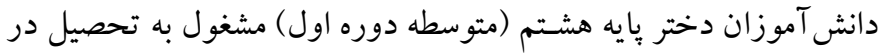
مدارس دولتى نواحى دو، سه، و يازده شهر تهر ان در سال تحصيلى وهـ-

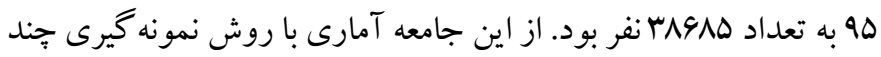

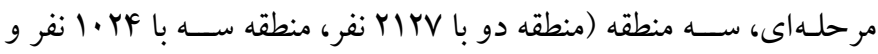

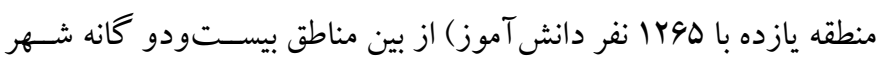
تهران به طور تصــادفى انتخاب شـــند. براى جلو گيرى از انتشــار عمل آزمايشى' از هر منطقه، يكك مدرسه دخترانهُ متوسطه دوره اول (از ميان

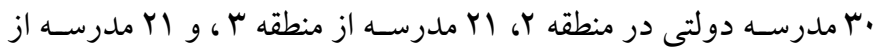

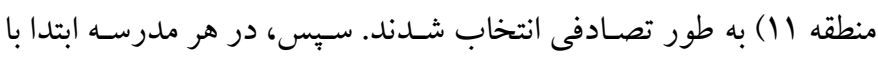

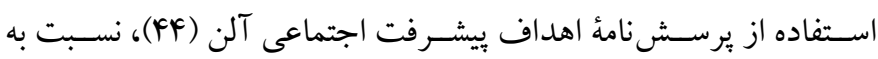
اندازه گيرى و تعيين طبقات اهداف ييشـرفت اجتماعى دانش آموزان بايه

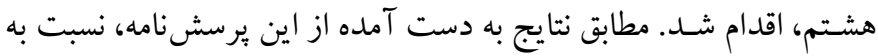

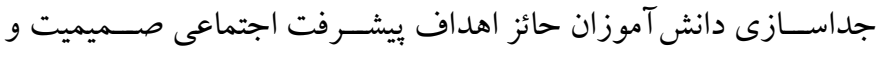

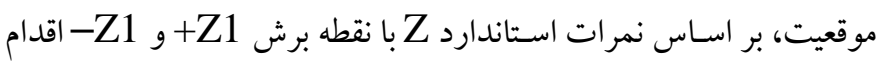

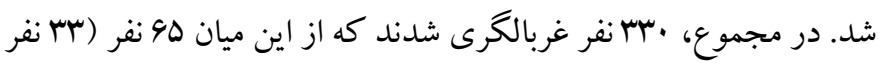

اجتماعى نشـان مىدهد كه كيفيت تعامل با والدين، معلمان، و همســالان

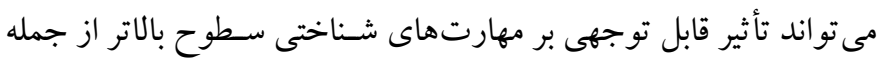
تفكر انتقادى و تحليلى داشته باشد (rV)

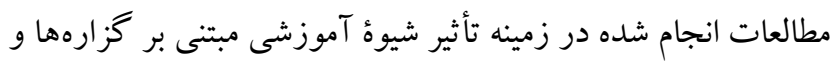
ادعاها بر بهبود مهارتهاى تفكر انتقادى به نتايج متفاوتى دست يافتهاند.

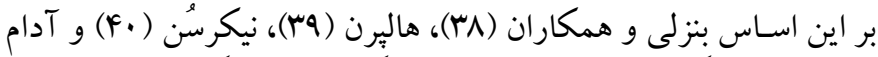

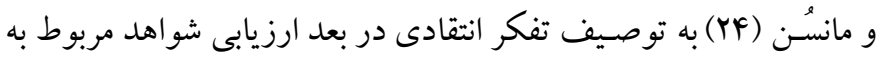

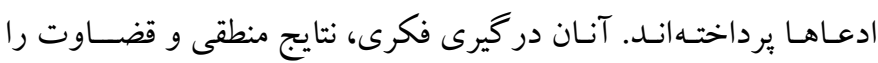

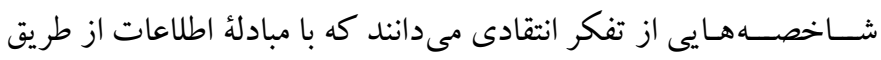

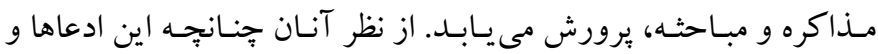
بحث ها با دقت ارزيابى شـود، مى تواند زمينه ساز بروز تفكر نقاد در افراد

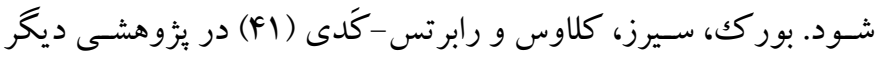

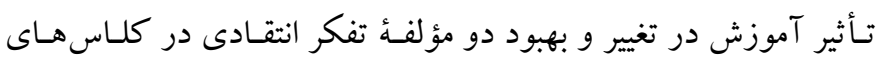
فلسفه و روانشناسى را بررسى كردند. دو مؤلفهُ تفكر انتقادى كه در اين

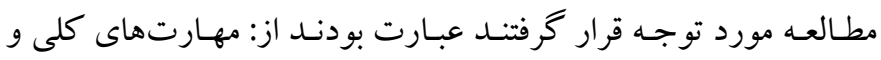
V. باورهاى شخصى. در داخل كشور براى اولين بار بدرى و قناعت ييشه

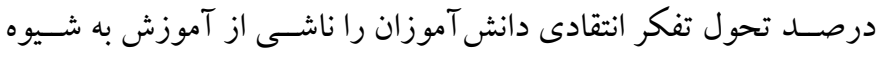

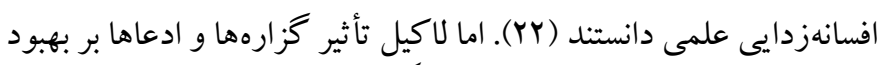

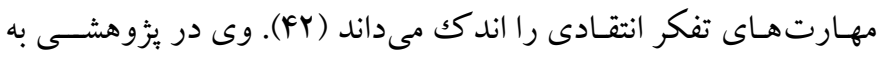

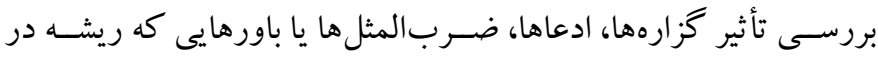

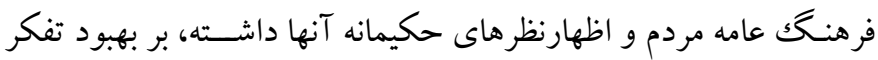

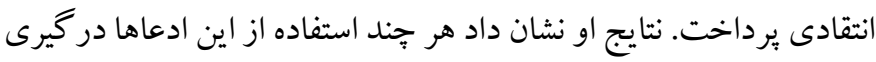
بيشتر و يردازش عميق ترى از اطلاعات را در بين فراخيران تسهيل كرده و

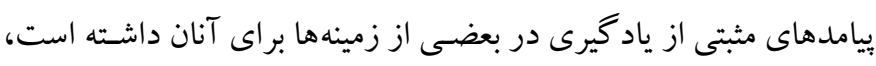

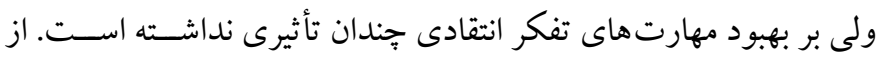
ســـى ديخر با وجود اهميت انخيزش اجتماعى در مدرسـه، يزوه هش در

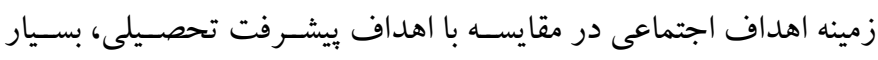

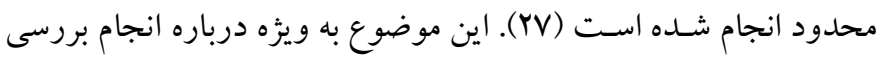

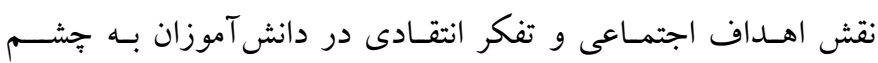

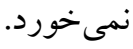


اجتمـاعى بـه ترتيـب بهترين بيشبينى كننده اهداف اجتماعى بالا و بايين

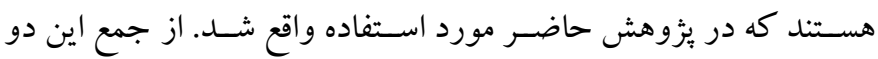

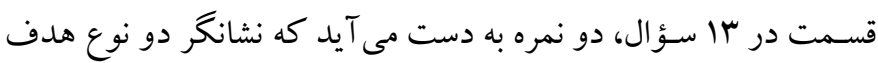

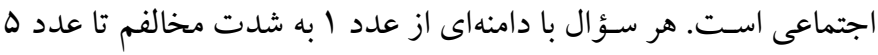
به شدت مخالفم درجهبندى شده است. مثالى از هدف اجتماعى بالا مانند

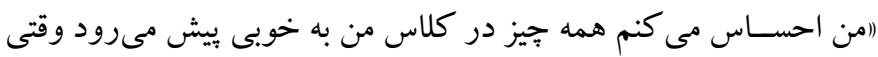

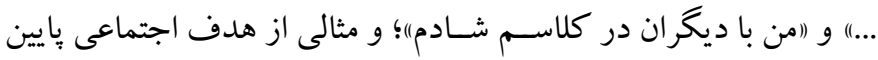

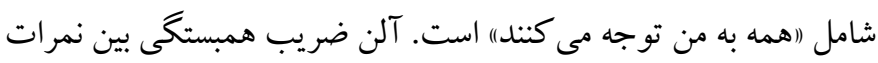

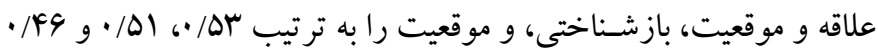

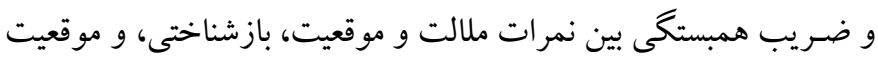

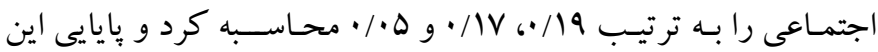

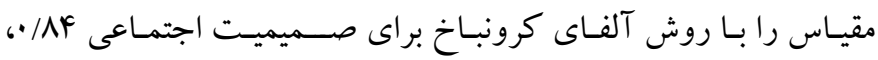

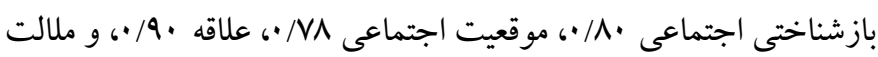
و خستكى

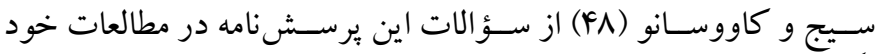
استفاده كردهاند و شاخصهاى آن را مورد تأييد قرار دادند.

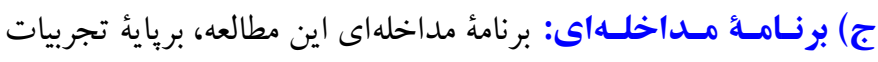

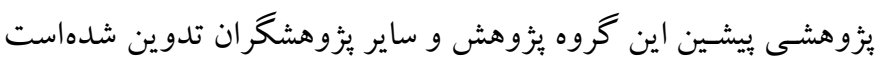

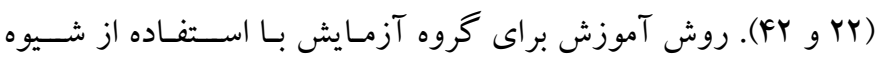

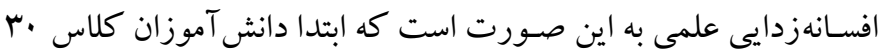
نفرى به 4 گروه ها نفرى تقسيم شدند و بر اساس محتواى درسى صنى تفكر و

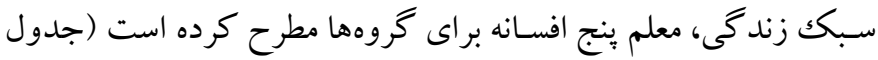

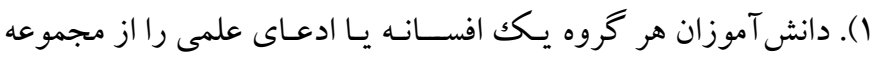

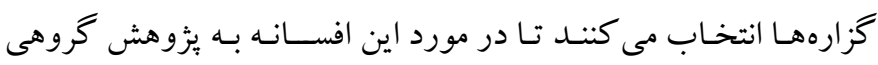

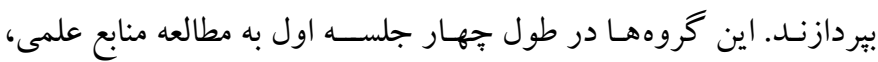
جمع آورى اطلاعات، و ارزيابى آنها بهصورت گروهى برداختند. معلم در

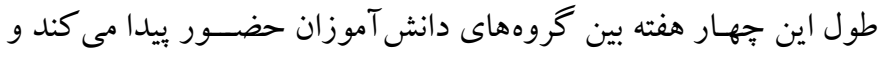

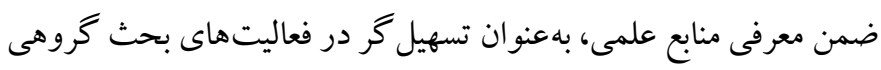

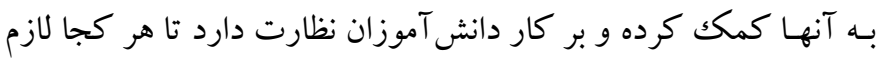

3. Social motivational orientations in sport scale (SMOSS)

4. Affiliation, social status, and social recognition
هدف اجتماعى سطح بالا و r نفر هدف اجتماعى سطح بايين) به شيوه

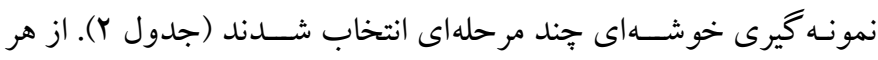

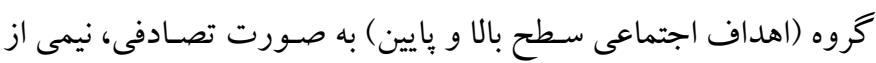

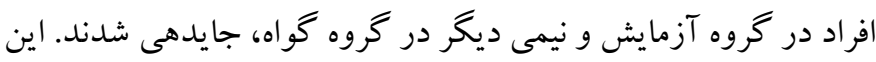

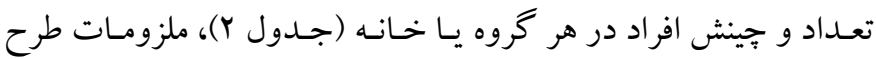
عاملى را بر آورده مى كند (FD).

ب) (بزارها 1. آزمون تنكر انتقادى كرنل ': اين مقياس كه در سال ه19 ا توسط انيس براى كود كان \& F - ـ ساخته شد، داراى V9 سؤ ال بوده، و با روش تحليل

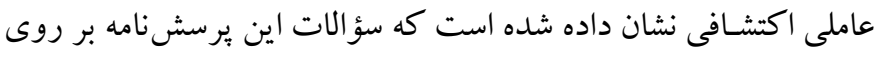

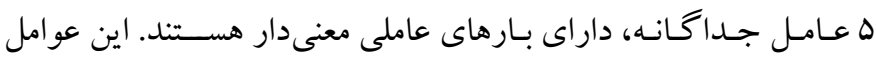

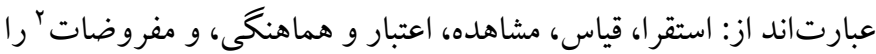

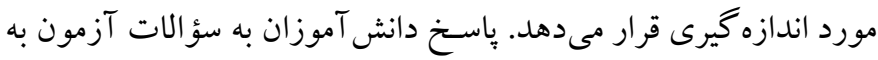

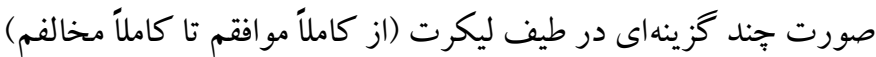
اسـت. انيس بايايى اين مقياس را با روش آلفاى كرونباخ براى مؤلفههاى

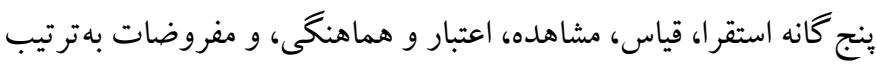

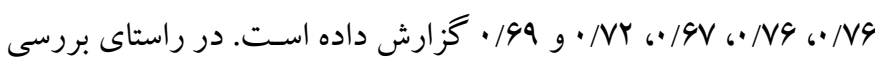
روايى سازة اين برسشنامه، انيس از روش تحليل عاملى اكتشافى استفاده

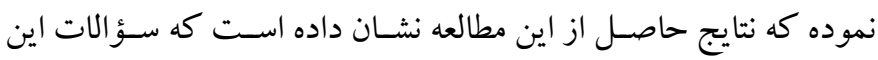

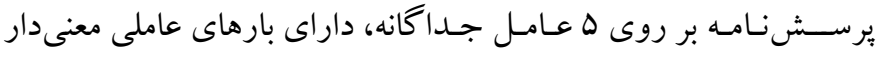

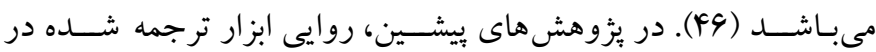

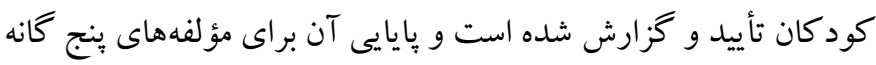

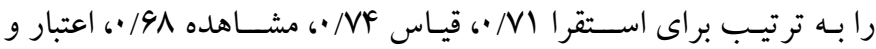
هماهنكى سr/ • و مفروضات 199/• بهدست آمده است (•r و r بr).

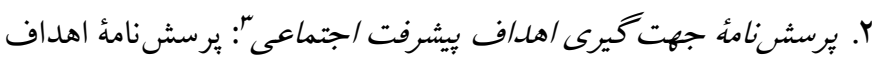

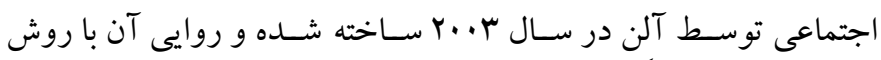
تحليل عاملى و بايايى آن در سـال ه. ب. توسط وى تعيين شد (FF). اين

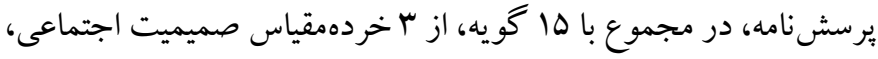

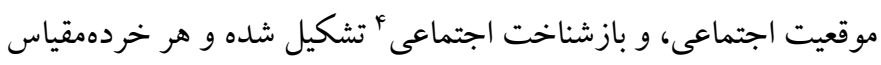

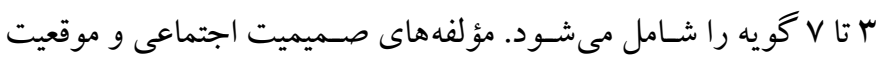

1. Cornell critical thinking test

2 . Induction, deduction, observation, credibility, assumption identification 
عنوان محتوا، جهت آموزش شيوه افسانهزدايى علمى انتخاب شد. منظور

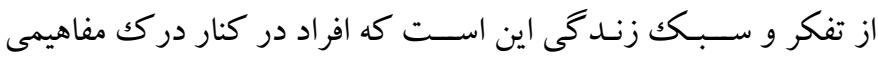

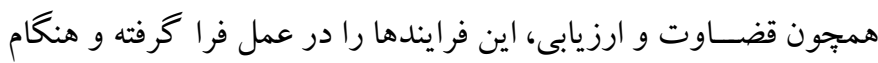

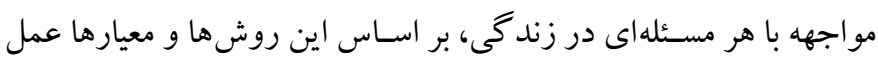

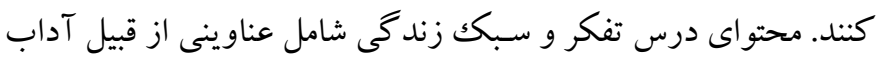

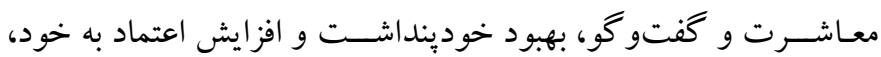
مهارتهاى مصرف، تصـميم گيرى، آداب سفر كردن، خويشتندارى، و و وند

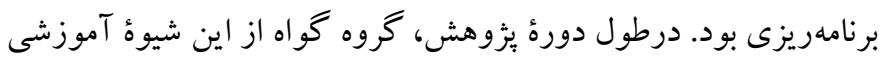

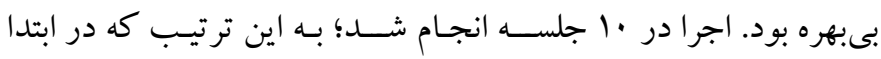

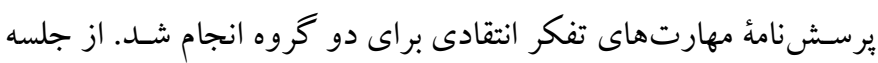

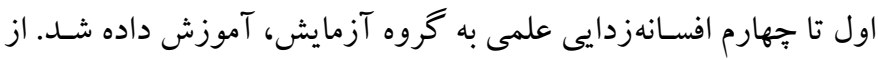

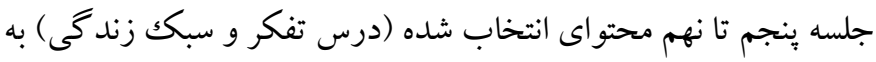

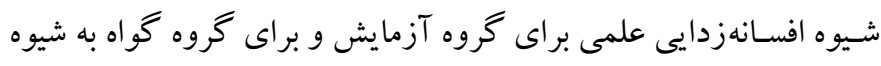

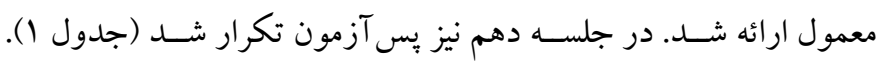

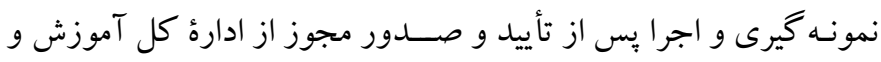
يرورش انجام يذيرفت و ملاحظات اخلاقى مانند حفظ گمنامى و محرمانه بودن اطلاعات در طول مطالعه و پِ از يُزوهش، لحاظ شد.
باشدف بازخوردهاى للازم ارائه كند و اعضاى هر گروه بتو انند با تلاش به سؤالات برسشنامه باسخ دهند. بعد از طى دوره جمع آورى و ارزيابى اطلاعات توسـط همه گروهها،

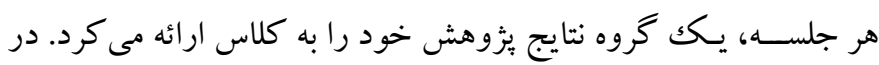

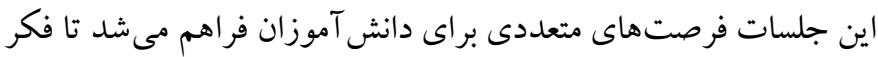

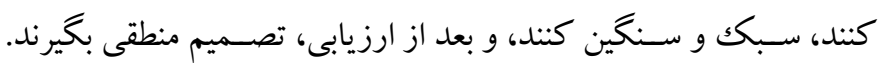

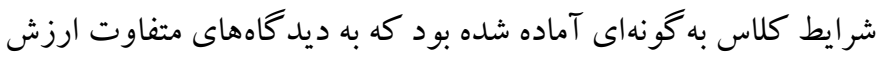

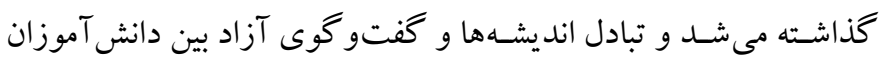

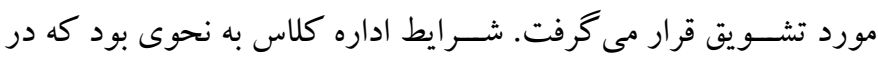

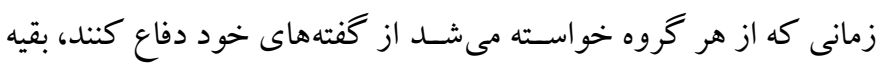

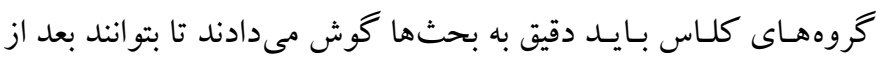

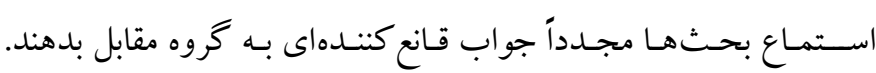

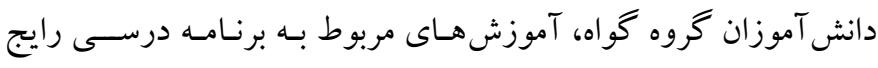
مدرسه را دنبال مى كردند. اين راهنما در جدول المور ارائه شده است.

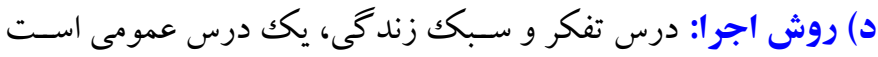

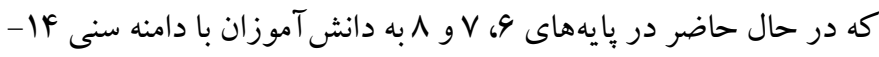

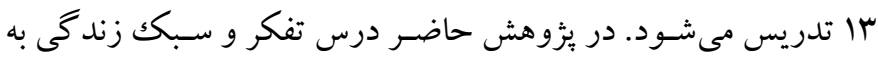

جدول ا: محتواى جلسات آموزش تفكر انتقادى با روش افسانهزدايى علمى

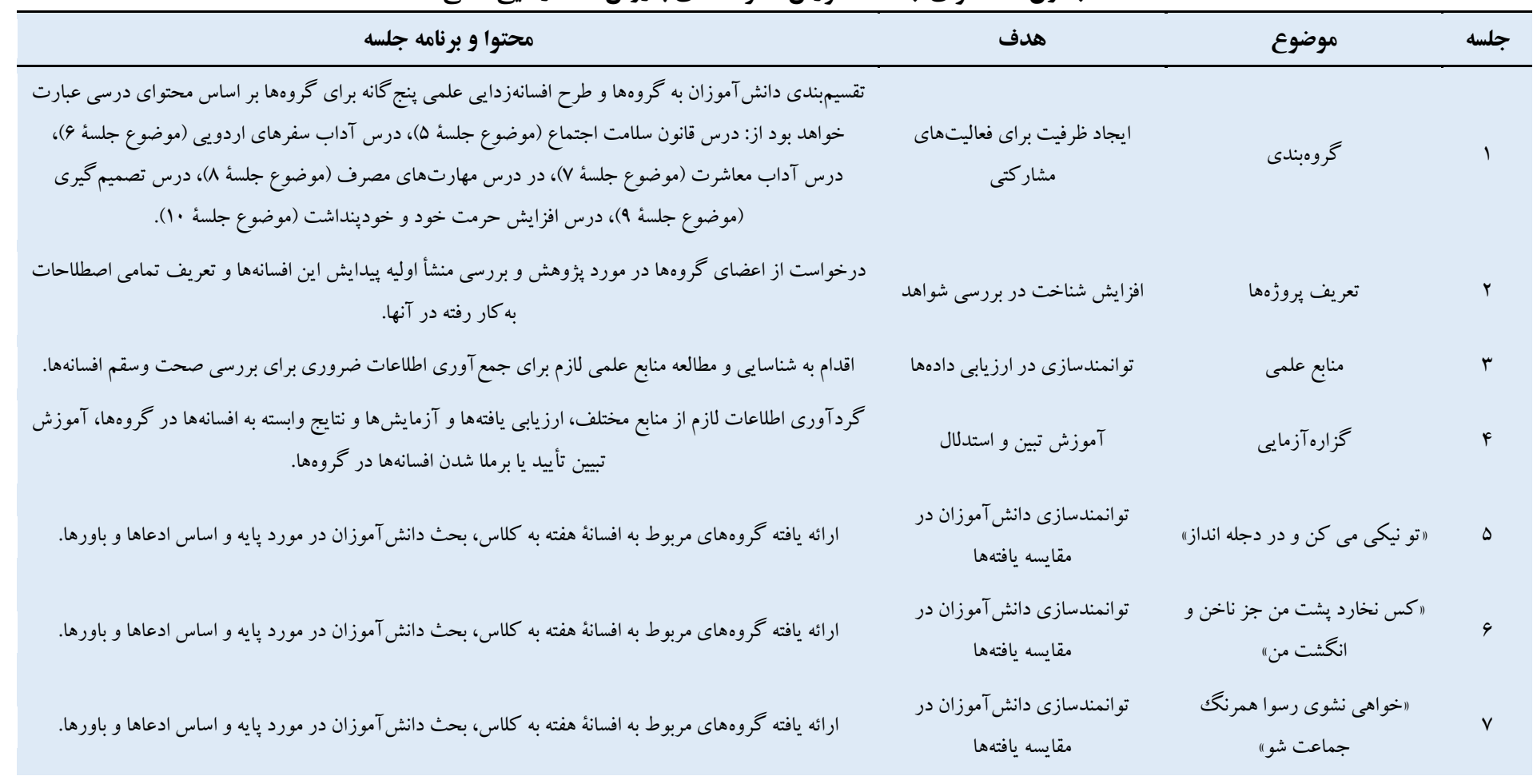


ارائه يافته گرووهاى مربوط به افسانه هفته به كلاس، بحث دانش آموزان در مورد بايه و اساس ادعاها و باورها.

ارائه يافته گروههاى مربوط به افسانه هفته به كلاس، بحث دانش آموزان در مورد بايه و اساس ادعاها و باورها.

ارائه يافته گروههاى مربوط به افسانه هفته به كلاس، بحث دانش آموزان در مورد بِايه و اساس ادعاها و باورها.
توانمندسازى دانش آموزان در

مقايسه يافتها

توانمندسازى دانش آموزان در

مقايسه يافتهها

توانمندسازى دانش آموزان در

مقايسه يافتها
|هيج گرانى بى حكمت نيست و هرار

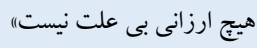

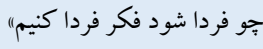

" آ آرزو بر جوانان عيب نيست"

يافته ها

در جـدول ب يافته هاى توصـيفى دو گروه آزمايش و گو اه را با توجه به

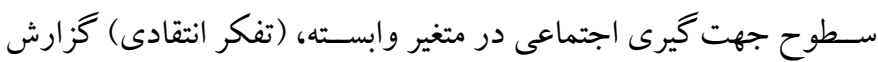

جدول r: شاخصهاى مر كزى و يراكندكى تفكر انتقادى در كروهها

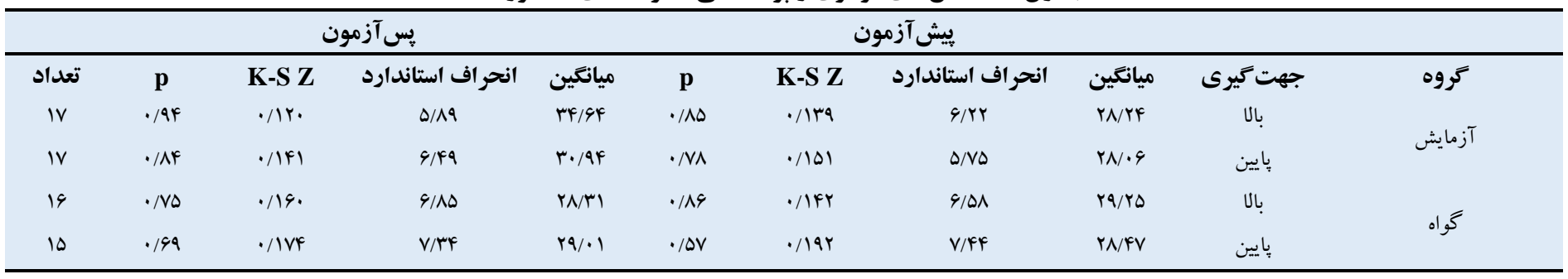

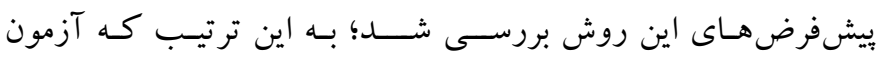

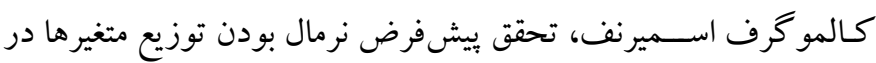

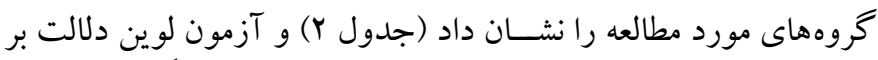

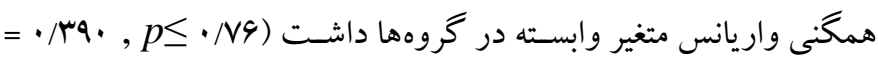

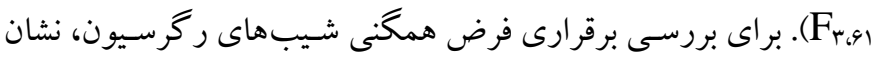

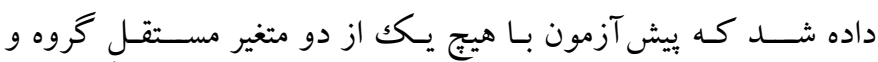

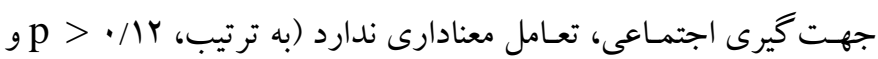

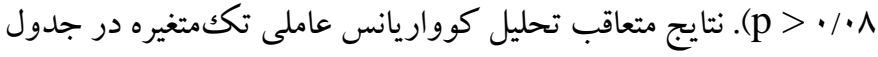

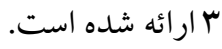

مندرجات جدول Y نشــان مىدهد كه توانائى تفكر انتقادى در گرووه آزمايشى كه داراى جهت اجتماعى بالا هستـند نسبت به افرادى كه حائز

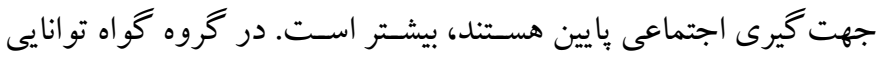
تفكر انتقادى در افرادى كه جهت كيرى اجتماعى بايين هستـند نسـبت به

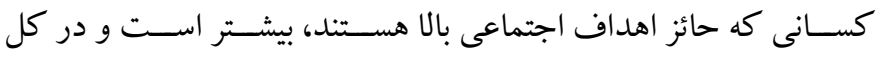

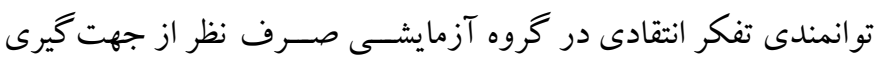

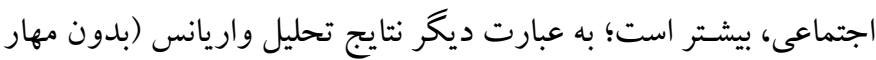

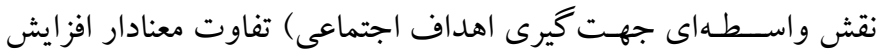
تفكر انتقادى در گروه آزمايشى را نشان مىدهد.

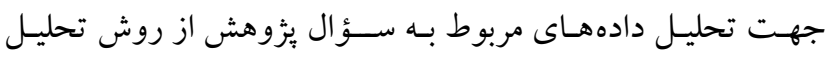

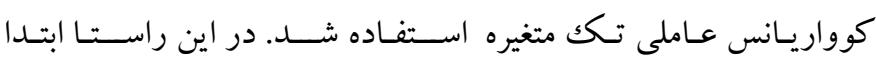

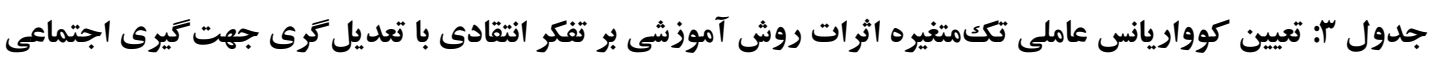

\begin{tabular}{|c|c|c|c|c|c|c|}
\hline ضريب اثر & سطح معنىدارى & $\mathbf{F}$ & ميانكين مجذورات & درجهُ آزادى & مجموع مجذورات & منبع متغير \\
\hline TrV &.$/ \cdots 1$ & $r 9 / .1$ & raN/9V & 1 & ran & كروه \\
\hline. & $\cdot / 1 \wedge$ & l/Ar & IN/A. & 1 & IN/A. & جهت گيرى اجتماعى \\
\hline \multirow[t]{2}{*}{.$/ 1 F$} & $\%$ & $9 / 94$ & १४/V४ & 1 & Q४/VG & گروه X جهت گيرى اجتماعى \\
\hline & & & $1 \cdot / \pi r$ & 4. & Glf/IV & خطا \\
\hline
\end{tabular}


افســانـز زدايى با اسـتففاده از ادعاهاى علمى و غيرعلمى اســت و اين با

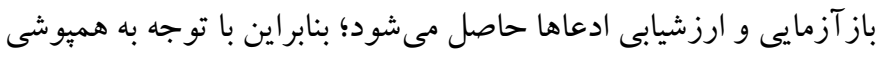

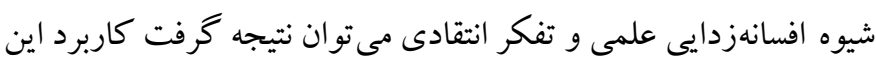

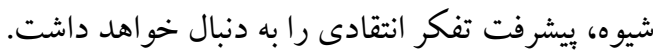

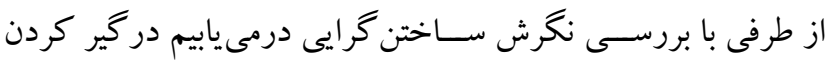

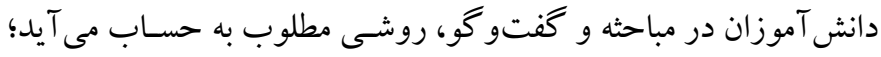

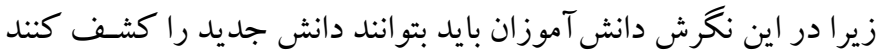

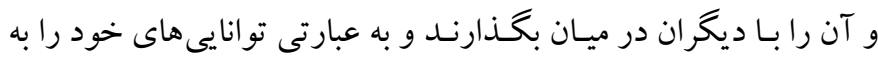

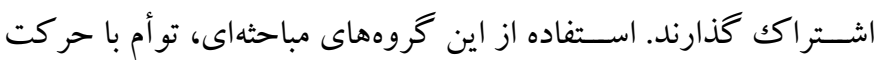

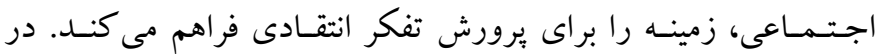

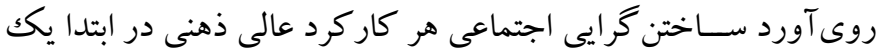

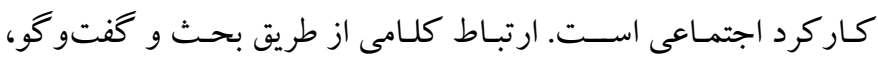

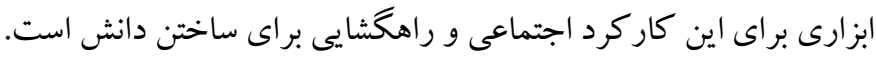

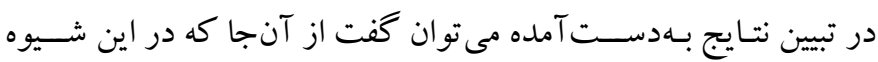

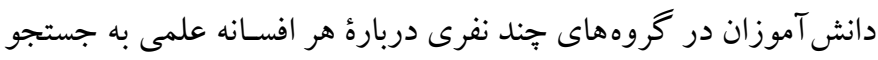

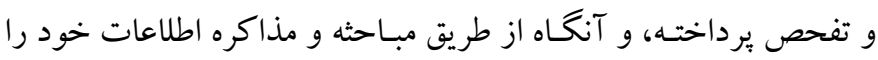

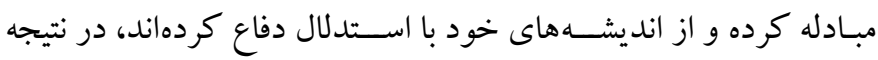
تو انستـند در اين فرايند توانايى للازم را براى ارزيابى انديشهـها و انتقادات خود و ديخران به دست آوردند. بر اسـاس نظر لودن، نوجوانان به منظور دستيابى به اهداف اجتماعى،

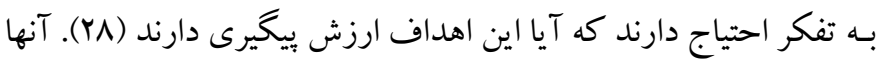

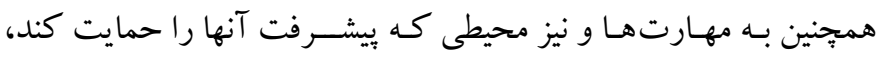

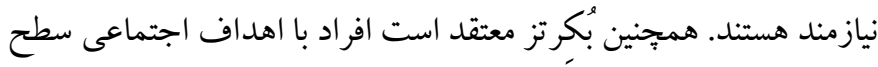

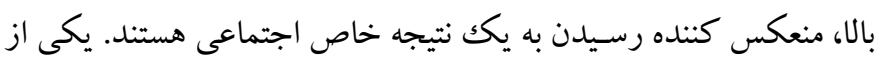

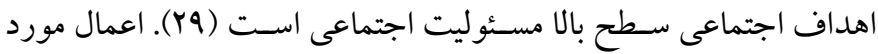
اسـتفاده در خدمت اهداف مسـئوليت اجتماعى شـامل در گير شـدن در فعاليتهاى علمى فوق برنامه، داوطلب شدن براى كارهاى كلاس درس،

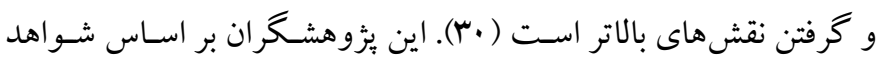
نظرى و تجربى در ارتباط با اهداف اجتماعى بيشـنهاد كردهاند استفاده از

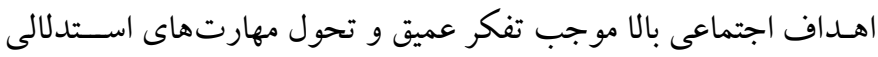
دانش آموزان مىشود. به همين دليل صاحبنظران در دهه حاضر جوانب مختلف اهداف اجتماعى را مورد مطالعه قرار داده و بر ضرورت شناسايى دمردي
منـدرجـات جـدول ب نشـــان مىدهــ كـه الف) آموزش مبتنى بر افسـانهزدايى علمى بر بهبود تفكر انتقادى از نظر آمارى معنىدار اســت

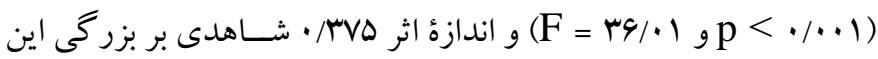

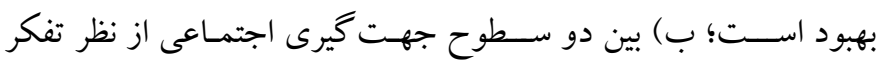

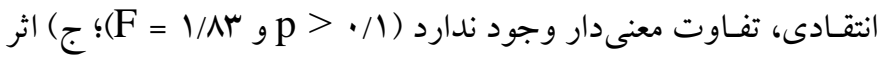
تعـامـل جهـت گيرى اجتمـاعى و روش آموزش بر تفكر انتقـادى از نظر

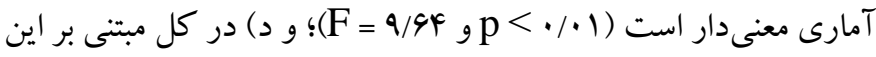

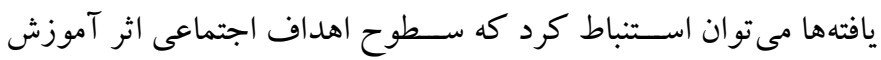

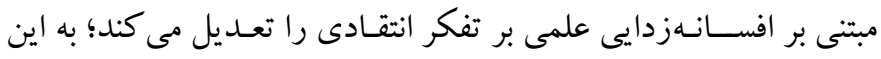

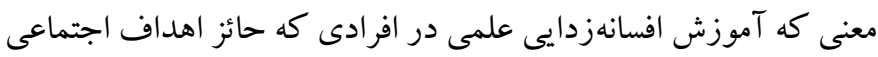

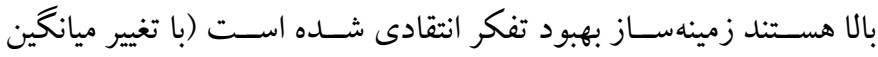

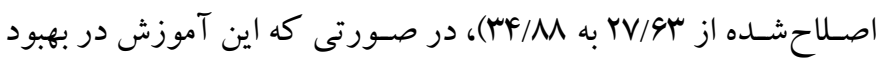

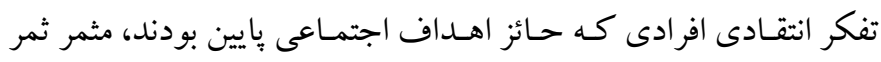

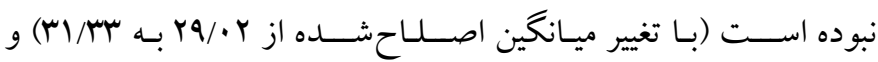

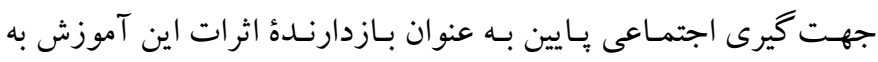
بهبود تفكر انتقادى، عمل كرده است.

\section{بحث و نتيجه كيرى} يافته هاى حاصل از يزؤهش حاضر نشان داد آموزش به شيوه افسانهزدايى

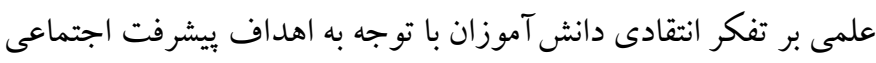

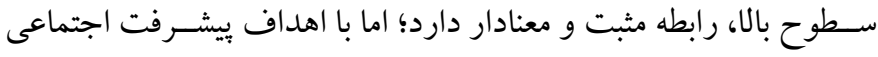
هايين معنادار نيست. نتايج به دست آمده در زمينه رابطه شيوه افسانهزدايى

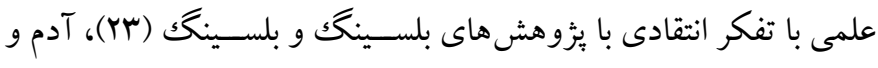

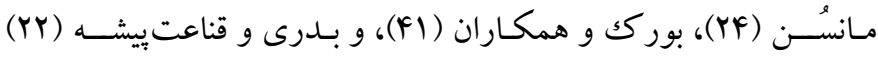
همخوان است. آنها نشان دادند آموزش به شيوه بررسى ادعاها و كزارهها موجب ييشرفت بيشتر تفكر انتقادى دانش آموزان مىشود. در تبيين نتايج

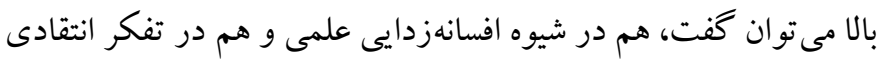

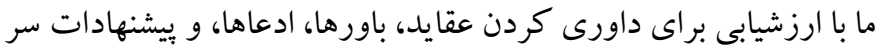
و كار داريم. ارزشيابى به معناى سنجش استحكام منطقى مفاهيم، عبارات

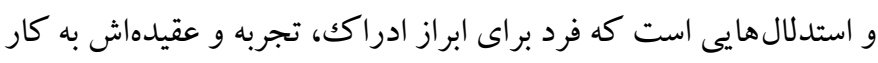

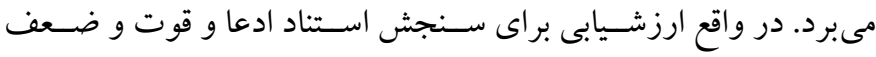

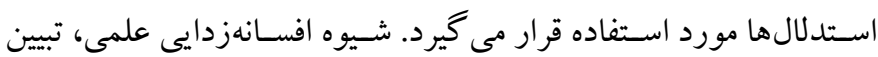


در همين راسـتا موقعيت فراكير در جهت برسـشـــرى با توجه به

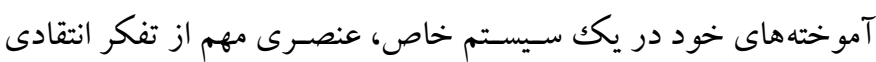

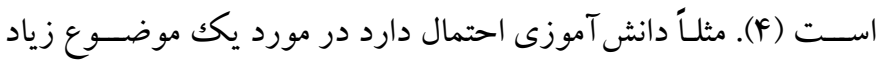

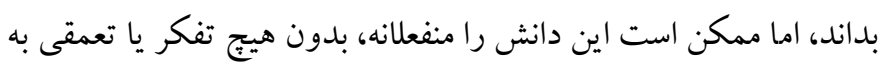

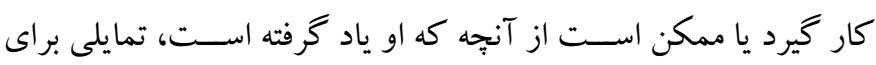

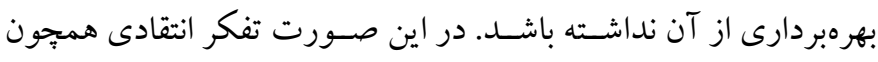

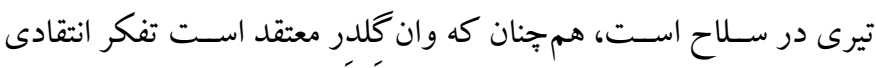

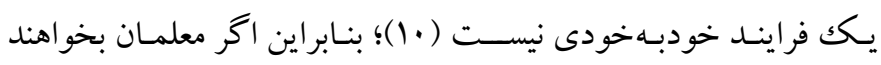

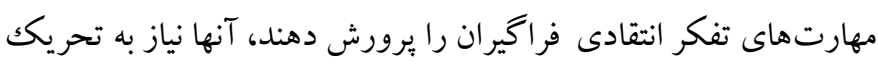

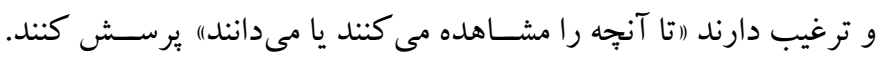

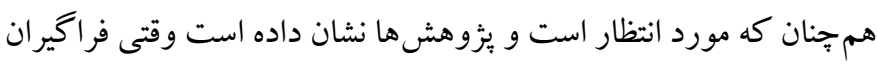

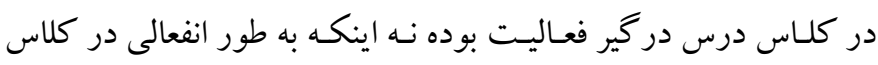

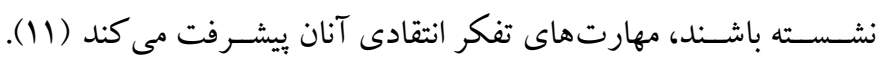

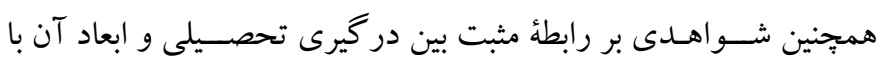

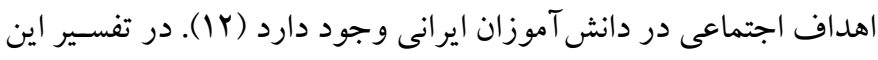

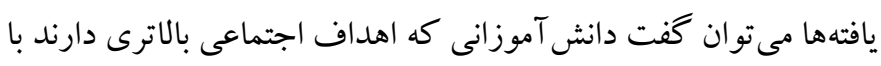

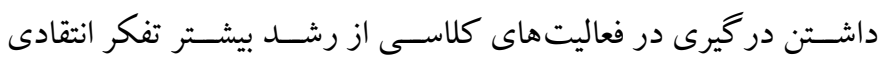

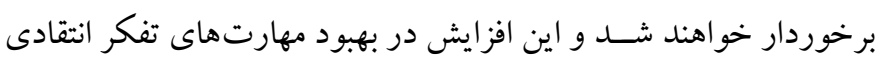
ممكن است در برتو شيوه افسانهزدايى علمى محقق شده باشد إند.

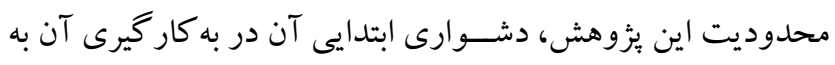
دليل نياز به سـرمايه كذارى زمانى فراوان و فعاليت زياد از ســوى معلمان

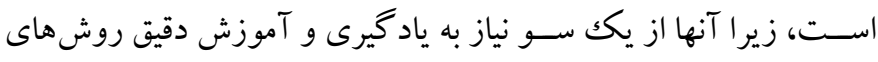

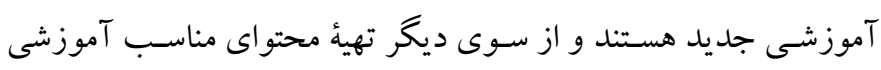

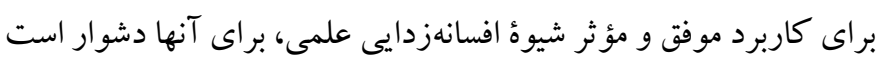

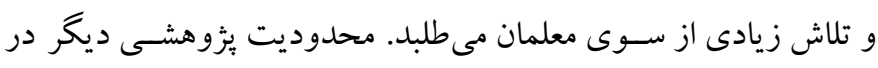

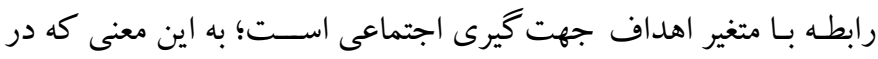

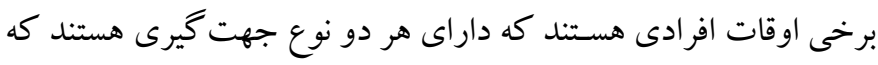

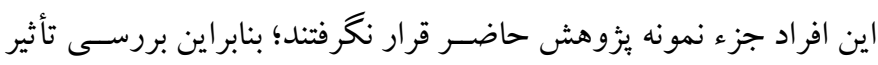

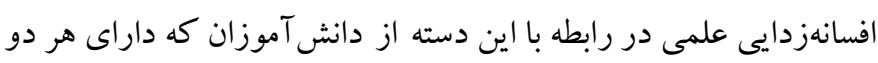
نوع جهت گيرى هستند، به صورت سؤ ال باقى مى ماند.
جهـت گيرى اهـداف بيشـــــت اجتماعى دانش آموزان در كلاس درس تأكيد كردهاند.

همجنين رايان و شيم يكى از اهداف شايستخى اجتماعى' را بيشرفت

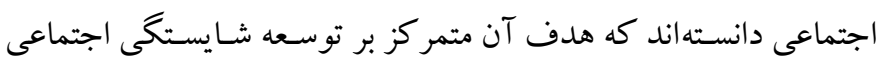

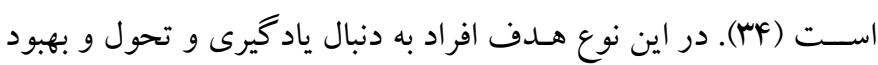

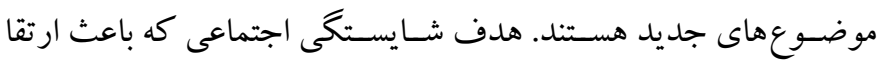

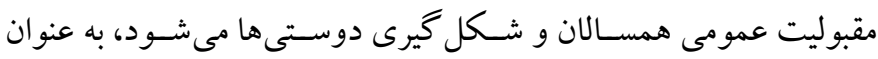

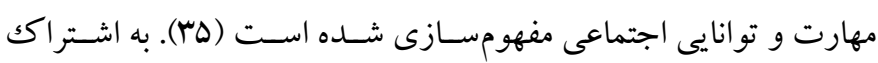

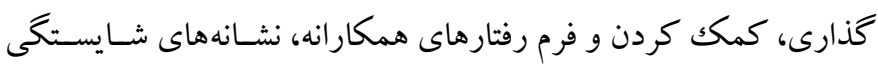

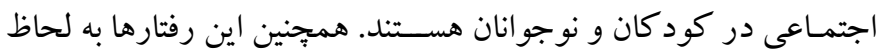

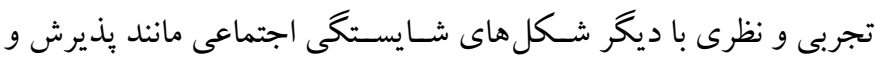

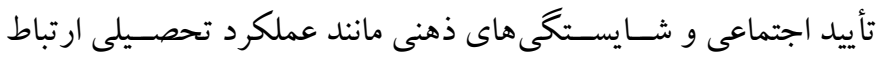

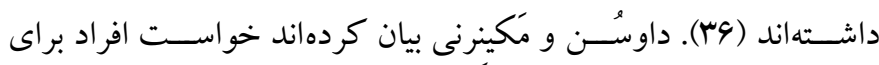

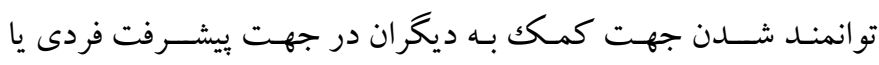

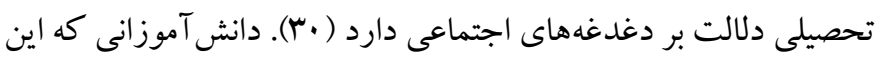

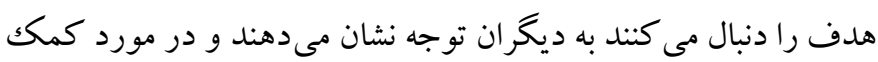

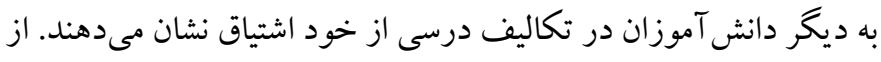

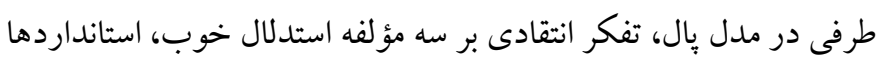

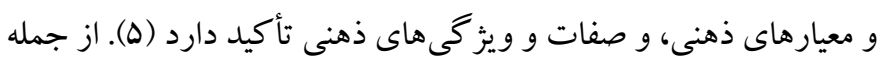

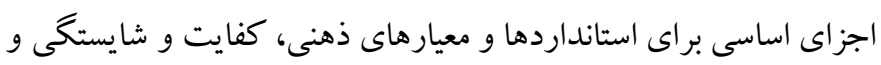

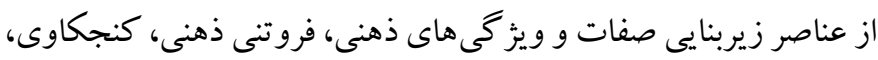

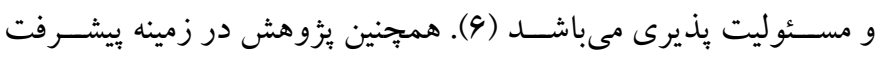

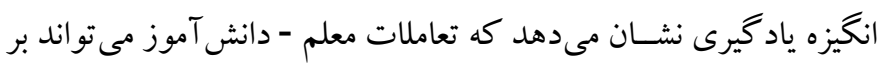

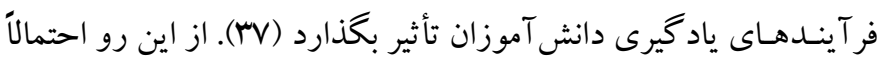

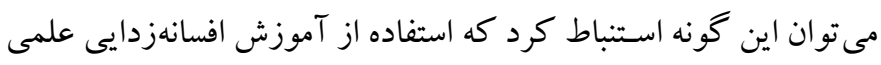
در دانش آموزان باعث شـده است تا آنها در فعاليتهاى علمى مشار كت

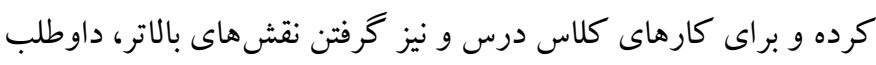

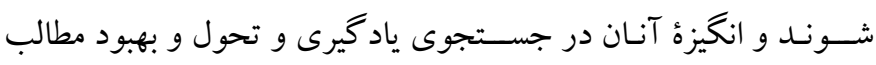

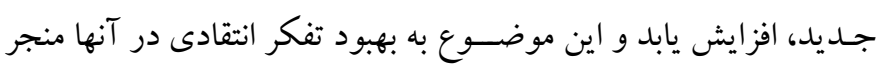
شله است. 
همجنين بيشـنهاد مى شود با توجه به اينكه احتمال تأثير انواع جهت گيرى

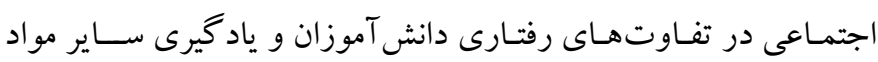

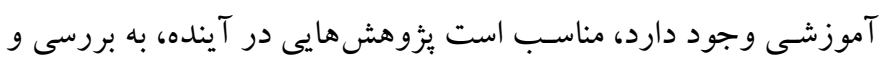

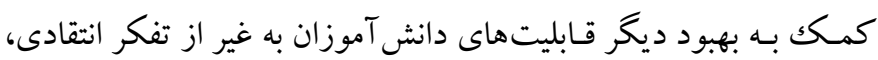

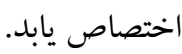

تشــكر و قدردانى: اين يثزوهش بر خرفته از رسـاله دكترا خانم عترت الزهرا

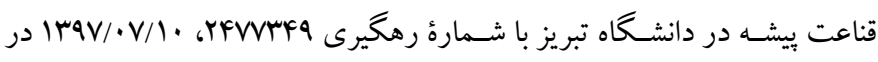

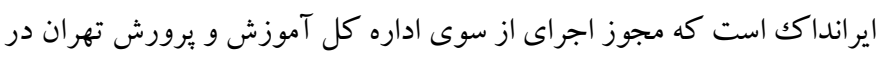

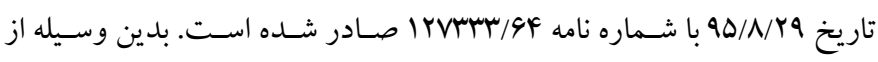

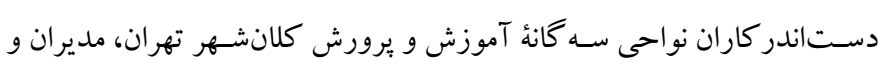
مربيـان مـدارس، و تمـامى افراد نمونسه به خاطر همكارى در اجر ائ اين مطالعها، صميمانه تقدير و تشكر مى شود.

تضاد منافع: نويسندكان اين مقاله هيج گونه تضاد منافعى در اين يزوهش

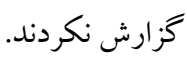

بيشـنهاد مشخص اين بثزوهش استفاده از روش افسانهزدايى علمى در

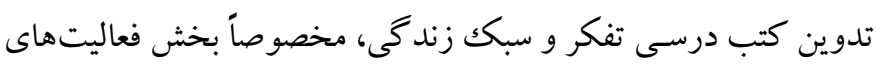

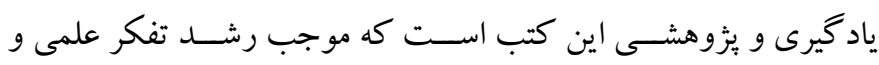

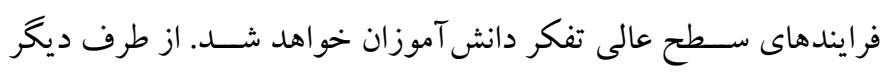

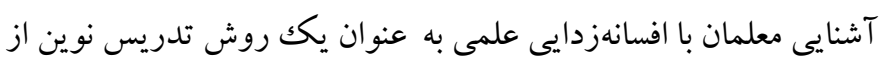

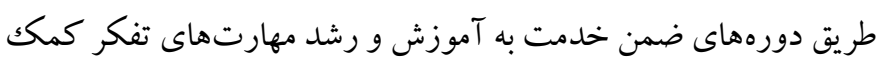
خو اهد كرد. مطالعه اثرات بلندمدت شـيوه افسـانهز دايى علمى، مطالعات

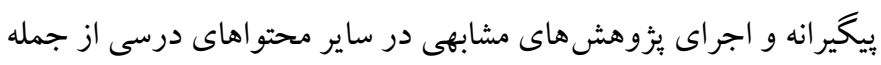
ييشنهادها براى يُزوهشخران آينده است.

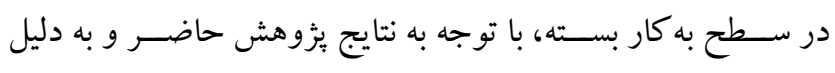

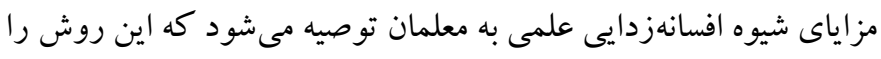

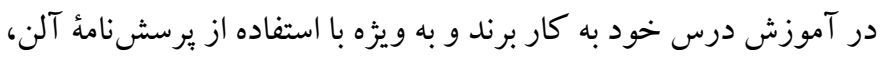

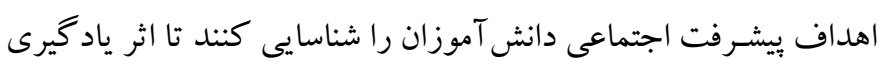

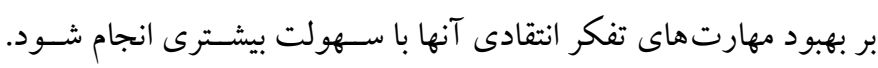




\section{References}

1. Alexander PA. Thinking Critically and Analytically about Critical-Analytic Thinking: an Introduction. Educ Psychol Rev. 2014; 26(4): 469-476. [Link]

2. Halpern DF. Thought and Knowledge: An introduction to critical thinking. 5th Edition. New York: Psychology Press; 2013, pp: 2-53. [Link]

3. Paul RW, Elder L. Critical thinking: Tools for taking charge of your professional and personal life. 2th Edition. Indianapolis, IN: Pearson FT Press; 2013, pp: 1-480. [Link]

4. Facione PA, Facione NC. Talking critical thinking. Change. 2007; 39(2): 38-45. [Link]

5. Yang Y-TC. Use of structured Web -based bulletin board discussions with Socratic questioning to enhance students' critical thinking skills in distance education [PhD Dissertation]. [West Lafayette, IN, USA]: Department of Curriculum and Instruction, Purdue University; 2002. [Link]

6. VeisKarami HA, Garavand H, NaserianHjiabadi H, Afsharizadeh SE, Montazeri R, Mohammadzade Ghasr A. A comparative study of functions of thinking style and self-directed learning among nursing and midwifery students in Mashhad. Research in Medical Education. 2012; 4(2): 53-62. [Persian]. [Link]

7. Browne MN, Keeley SM. Asking the right questions : A guide to critical thinking. 12th ed. New York, NY: Pearson; 2017. [Link]

8. Ku KYL. Assessing students' critical thinking performance: Urging for measurements using multiresponse format. Think Skills Creat. 2009; 4(1): 7076. [Link]

9. Pintrich PR, Marx RW, Boyle RA. Beyond cold conceptual change: The role of motivational beliefs and classroom contextual factors in the process of conceptual change. Rev Educ Res. 1993; 63(2): 167199. [Link]

10. van Gelder T. Teaching critical thinking: Some lessons from cognitive science. College Teaching. 2005; 53(1): 41-48. [Link]

11. Piergiovanni PR. Creating a critical thinker. College Teaching. 2014; 62(3): 86-93. [Link]

12. Shamsoddini Lori G. Achievement goals and academic engagement: The mediating factor of social goals [Master's Thesis]. [Tehran, Iran]: Faculty of Psychology and Education, University of Tehran; 2015. [Persian].

13. Song X. "Critical thinking" and pedagogical implications for higher education. East Asia. 2016; 33(1): 25-40. [Link]
14. Golding C. Educating for critical thinking: Thought-encouraging questions in a community of inquiry. Higher Education Research \& Development. 2011; 30(3): 357-370. [Link]

15. Snodgrass S. Wiki activities in blended learning for health professional students: Enhancing critical thinking and clinical reasoning skills. Australasian Journal of Educational Technology. 2011; 27(4): 563580. [Link]

16. Popil I. Promotion of critical thinking by using case studies as teaching method. Nurse Educ Today. 2011; 31(2): 204-207. [Link]

17. Richardson JC, Ice P. Investigating students' level of critical thinking across instructional strategies in online discussions. Internet High Educ. 2010; 13(1-2): 52-59. [Link]

18. Caplan PJ. Teaching critical thinking about psychology of sex and gender. Psychol Women Q. 2010; 34(4): 553-557. [Link]

19. Lun VM-C, Fischer R, Ward C. Exploring cultural differences in critical thinking: Is it about my thinking style or the language I speak? Learn Individ Differ. 2010; 20(6): 604-616. [Link]

20. Badri R, Khanlari M. The effect of teaching the strategy of "guided reciprocal peer questioning" on third graders female students' critical thinking in secondary school. Thinking and Children. 2014; 4(8): 1-16. [Persian]. [Link]

21. Fat'hi Azar E, Badri Gargari R, Ahrari G. The effects of bono's six hats technique on students' critical thinking and creativity. Quarterly Journal of Innovation and Creativity in Human Sciences. 2014; 4(1): 159-188. [Persian]. [Link]

22. Badri Gargari R, Ghanaatpishe E. Effectiveness of science myth buster teaching method on critical thinking of students. Quarterly Journal of Educational Innovations. 2015; 14(3): 7-21. [Persian]. [Link]

23. Blessing SB, Blessing JS. PsychBusters: A means of fostering critical thinking in the introductory course. Teach Psychol. 2010; 37(3): 178-182. [Link]

24. Adam A, Manson TM. Using a pseudoscience activity to teach critical thinking. Teach Psychol. 2014; 41(2): 130-134. [Link]

25. Scriven M, Paul RW. Defining critical thinking [Conference Report]. [Rohnert Park, United States]: 8th Annual International Conference on Critical Thinking and Education Reform; 1987. [Link]

26. Riggs LW, Hellyer-Riggs S. Development and motivation in/for critical thinking. J Coll Teach Learn. 2014; 11(1): 1-8. [Link] 
27. Makara KA, Madjar N. The role of goal structures and peer climate in trajectories of social achievement goals during high school. Dev Psychol. 2015; 51(4): 473-488. [Link]

28. Ludden AB. Social goals, social status, and problem behavior among low-achieving and high-achieving adolescents from rural schools. Journal of Research in Rural Education. 2012; 27(7): 1-19. [Link]

29. Boekaerts M, de Koning E, Vedder P. Goal-directed behavior and contextual factors in the classroom: An innovative approach to the study of multiple goals. Educ Psychol. 2006; 41(1): 33-51. [Link]

30. Dowson M, McInerney DM. The development and validation of the goal orientation and learning strategies survey (Goals-S). Educ Psychol Meas. 2004; 64(2): 290-310. [Link]

31. Ford ME. Motivational opportunities and obstacles associated with social responsibility and caring behavior in school contexts. In: Juvonen J, Wentzel KR, editors. Social motivation: Understanding children's school adjustment. Cambridge: Cambridge University Press; 1996, pp: 126-153. [Link]

32. Kiefer SM, Ryan AM. Striving for social dominance over peers: The implications for academic adjustment during early adolescence. J Educ Psychol. 2008; 100(2): 417-428. [Link]

33. Roussel P, Elliot AJ, Feltman R. The influence of achievement goals and social goals on help-seeking from peers in an academic context. Learn Instr. 2011; 21(3): 394-402. [Link]

34. Ryan AM, Shim SS. Social achievement goals: The nature and consequences of different orientations toward social competence. Pers Soc Psychol Bull. 2006; 32(9): 1246-1263. [Link]

35. Rubin KH, Coplan RJ, Chen X, Bowker JC, McDonald KL, Heverly-Fitt S. Peer relationships. In: Bornstein MH, Lamb ME, editors. Developmental science: An advanced textbook. 7th ed. New York, NY: Psychology Press; 2016, pp: 591-649. [Link]

36. Newcomb AF, Bukowski WM, Pattee L. Children's peer relations: A meta-analytic review of popular, rejected, neglected, controversial, and average sociometric status. Psychol Bull. 1993; 113(1): 99128. [Link]

37. Wentzel KR. Teacher-Students relationships. In: Wentzel KR, Miele DB, editors. Handbook of motivation at school. 2th Edition. New York: Routledge; 2016, pp: 211-230. [Link]

38. Bensley DA, Crowe DS, Bernhardt P, Buckner C, Allman AL. Teaching and assessing critical thinking skills for argument analysis in psychology. Teach Psychol. 2010; 37(2): 91-96. [Link]

39. Halpern DF. Teaching critical thinking for transfer across domains: Disposition, skills, structure training, and metacognitive monitoring. Am Psychol. 1998; 53(4): 449-455. [Link]

40. Nickerson RS. Why teach thinking? In: Baron JB, Sternberg RJ, editors. Teaching thinking skills: Theory and practice. New York, NY: Freeman; 1987, pp: 27-37. [Link]

41. Burke BL, Sears SR, Kraus S, Roberts-Cady S. Critical analysis: A comparison of critical thinking changes in psychology and philosophy classes. Teach Psychol. 2014; 41(1): 28-36. [Link]

42. LaCaille RA. Two birds with one myth-debunking campaign: Engaging students to target psychological misconceptions. Teach Psychol. 2015; 42(4): $323-$ 329. [Link]

43. Ghanaat Pisheh EA, NejatyJahromy Y, Badri Gargari R, Hashemi T, Fathi-Azar E. Effectiveness of clicker-assisted teaching in improving the critical thinking of adolescent learners. J Comput Assist Learn. 2019; 35(1): 82-88. [Link]

44. Allen JB. Measuring social motivational orientations in sport: An examination of the construct validity of the SMOSS. Int J Sport Exerc Psychol. 2005; 3(2): 147-161. [Link]

45. Gall MD, Gall JP, Borg WR. Educational research : An introduction. 8th Edition. Boston, MA: Pearson; 2006, pp: 401-432. [Link]

46. Ennis RH, Millman J, Tomko TN. Cornell critical thinking tests level X \& level Z: Manual. Pacific Grove, CA: Midwest Publications; 1985, pp: 2-56. [Link]

47. Garn AC, McCaughtry N, Shen B, Martin JJ, Fahlman M. Social Goals in urban physical education: relationships with effort and disruptive behavior. J Teach Phys Educ. 2011; 30(4): 410-423. [Link]

48. Sage L, Kavussanu M. Moral identity and social goals predict eudaimonia in football. Psychol Sport Exerc. 2010; 11(6): 461-466. [Link] 